Article

\title{
Design, Synthesis and Biological Activity Evaluation of Arylpiperazine Derivatives for the Treatment of Neuropathic Pain
}

Yin Chen ${ }^{1}$, Guan Wang ${ }^{2}$, Xiangqing Xu ${ }^{3}$, Bi-Feng Liu ${ }^{1}$, Jianqi Li ${ }^{2}$ and Guisen Zhang ${ }^{1,3, *}$

1 Department of Systems Biology, Huazhong University of Science and Technology, 1037 Luoyu Road, Wuhan, 430074, China

2 Shanghai Institute of Pharmaceutical Industry, 1111 North Zhongshan Road, Shanghai, 200437, China

3 Jiangsu Nhwa Pharmaceutical Corporation, Ltd. 69\# Minzhu South Road Xuzhou City, Jiangsu, 221009, China

* Author to whom correspondence should be addressed; E-Mail: gszhang@mail.hust.edu.cn; Tel.: +86-27-87792235; Fax: +86-27-87792170.

Received: 7 April 2011; in revised form: 24 June 2011 / Accepted: 27 June 2011 /

Published: 7 July 2011

\begin{abstract}
In this work, a series of arylpiperazine derivatives were synthesized and screened by in vivo pharmacological trials. Among the tested compounds, 2-(4-(3-(trifluoromethyl)phenyl)piperazin-1-yl)-1-phenylethanone and 2-(4-(2,3-dimethylphenyl)piperazin-1-yl)-1-phenylethanone (19) exhibited potent analgesic activities in both the mice writhing and mice hot plate tests. They showed more than $70 \%$ inhibition relative to controls in the writhing test, and increased latency by $116.0 \%$ and $134.4 \%$, respectively, in the hot plate test. Furthermore, compound $\mathbf{1 8}$ was also active in the models of formalin pain and neuropathic pain without sedative side effects.
\end{abstract}

Keywords: arylpiperazine; antinociceptive; neuropathic pain; spared nerve injury; chronic constriction injury 


\section{Introduction}

Neuropathic pain is a chronic, debilitating pain state that results from injury to the peripheral or central nervous system. It can be triggered by a variety of events or conditions, including diabetes, shingles, and chemotherapy [1,2]. Currently neuropathic pain is usually treated with a variety of drugs, including opioids, non-steroidal anti-inflammatory drugs (NSAIDs) and analgesic adjuvants [3]. As is well-known, opioids induce a wide variety of side effects, including sedation, constipation, respiratory depression, drug tolerance and physical dependence etc [4]. Meanwhile, NSAIDs show adverse reactions at the gastrointestinal level together with inhibition of platelet aggregation and renal toxicity [5]. The so-called "analgesic adjuvants", e.g., antidepressants, anticonvulsants and anesthetics [5-7], show some efficacy in the treatment of neuropathic pain [6-8]. However, these analgesic adjuvants have also shown limited effectiveness for neuropathic pain [9]. Therefore, the design and development of novel analgesic agents that can effectively cure neuropathic pains without inducing side effects remains a major challenge in biomedical research [10].

Piperazines are an important class of chemical compounds with a broad spectrum of biological activities [11-13], e.g., anti-infective, anti-cancer, anti-psychiatry, and antinociceptive. Compounds 1 and 2 (Figure 1) demonstrate favorable in vivo efficacy in the spinal nerve ligation model of neuropathic pain [14]. Compound 3 (JNJ1661010) attenuates tactile allodynia in the rat mild thermal injury model of acute tissue damage and in the rat spinal nerve ligation model of neuropathic pain [15]. Compound $\mathbf{4}$ is identified as a potent orally available N-type calcium channel blocker and exhibited mechanical and thermal analgesic activity in the rat spinal nerve ligation model [16]. Thus, piperazine derivatives are obviously attractive candidates for developing novel analgesic drugs.

Figure 1. Title and reference compounds.<smiles>[R]N1CCN(C(=O)c2ccc(-c3ccc(Cl)cc3)o2)CC1</smiles>

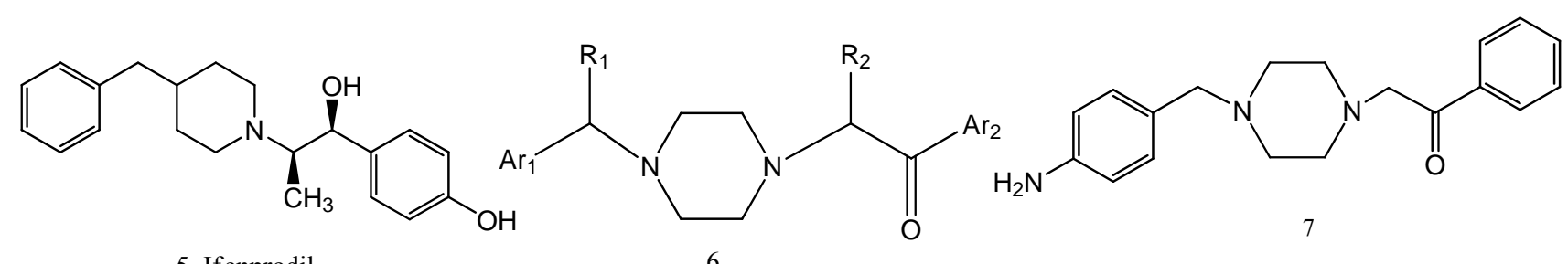

5 Ifenprodil

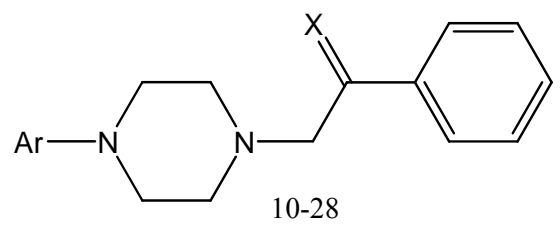


Ifenprodil (5) was one of the first generation selective NMDA receptor antagonists, which have been used as neuroprotective agents and peripheral expansion of drug for neuropathic pain [17]. In a previous work, a series of aralkylketone piperazine derivatives 6 were synthesized by referring to the active sites of ifenprodil, indicating potent analgesic activities in vivo [18]. Subsequent studies showed that SIPI5047 (7) had significant in vivo analgesic activities, similar to morphine. However, it induced a major sedative side effect of the nervous system [19]. In this work, we showed that removal of the carbon atom between $\mathrm{Ar}_{1}$ and the nitrogen atom of these compounds reduced the sedative side effects without losing analgesic efficacy. To further investigate the structural requirements for drugs capable of improved antinociceptive effects and reduced the sedative side effects, we designed compounds 10-28 (Scheme 1) based on the influence of a number of structural characteristics on antinociceptive effects, including: substituent with different electronic properties on the Ar aromatic ring, replacement of Ar with heterocycle moieties, replacement of carbonyl with the $\mathrm{C}=\mathrm{N}-\mathrm{OR}$ group.

\section{Results and Discussion}

\subsection{Chemistry}

Scheme 1 summarizes the routes for synthesizing compounds 10-28. Briefly, 2-chloro-1-phenylethanone were reacted with the arylpiperazined in the presence of $\mathrm{Na}_{2} \mathrm{CO}_{3}$ to yield compounds 10-25 [20], compounds 10 and 12 were then transformed into compounds 26-28 by reacting with hydroxylamine hydrochloride or $N$-ethylhydroxylamine hydrochloride. The compounds 10-28 were characterized by their physical and spectral data $\left({ }^{1} \mathrm{H}-\mathrm{NMR}\right.$ and mass spectrometry).

Scheme 1. Synthesis of the compounds 10-28.
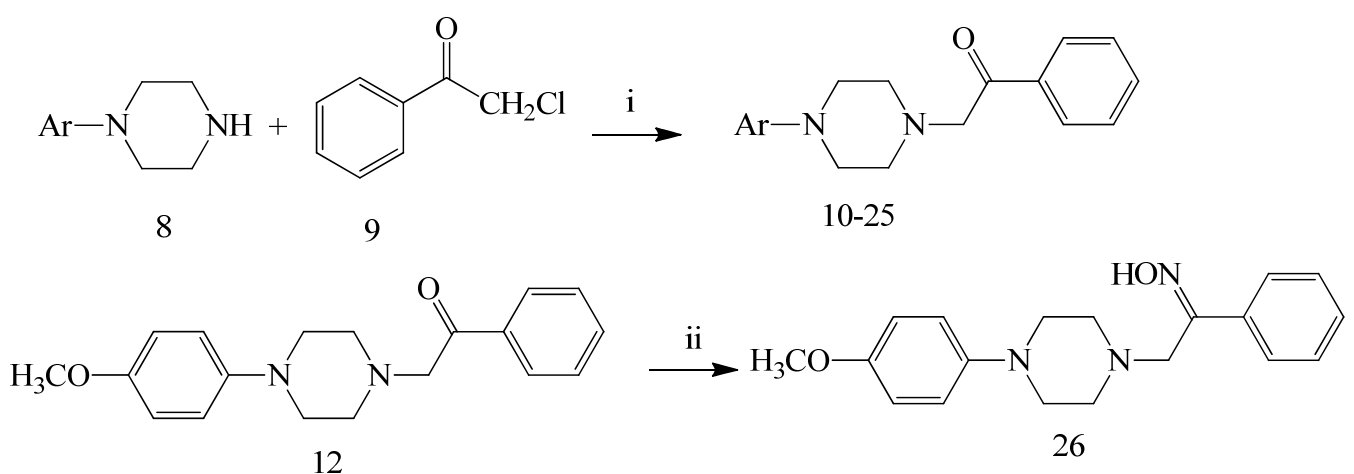

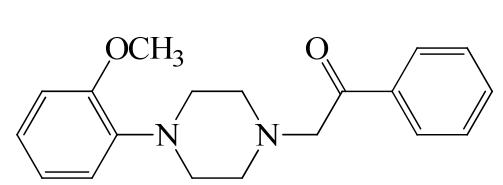

10

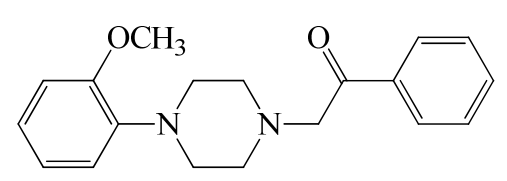

10

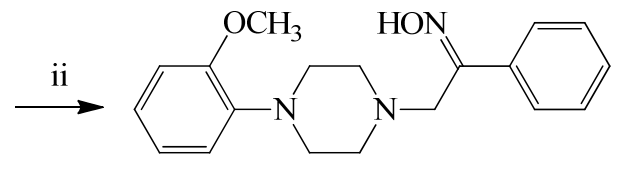

27

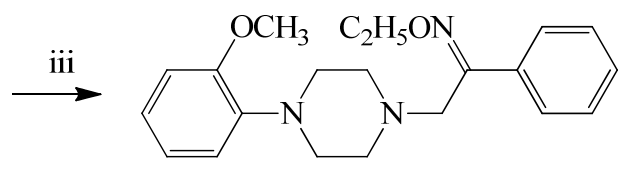

28

Reagents and conditions: (i) $\mathrm{C}_{2} \mathrm{H}_{5} \mathrm{OH}, \mathrm{Na}_{2} \mathrm{CO}_{3}$, reflux; (ii) $\mathrm{NH}_{2} \mathrm{OH}, \mathrm{NaOH}, \mathrm{C}_{2} \mathrm{H}_{5} \mathrm{OH}$; (iii) $N$-ethylhydroxylamine, $\mathrm{NaOH}, \mathrm{C}_{2} \mathrm{H}_{5} \mathrm{OH}$. 


\subsection{Hot Plate Test and Writhing Test}

Initially, the analgesic activities of compounds 10-28 were screened by both the acetic acid induced writhing test [21] and the hot plate test [22]. All compounds were administered po, and their efficacies were compared with acetylsalicylic acid and morphine. In the acetic acid induced writhing test, compounds 10, 11, 14, 15, 18, 19, 20, 24 and 25 were able to reduce the number of writhes while in contrast, other compounds could not reduce the number of writhes (Table 1). Compounds 18 (40 mg/kg) and $19(10 \mathrm{mg} / \mathrm{kg})$ were found to yield the best analgesic activities with $78.7 \%$ and $75.2 \%$ inhibition, respectively. It should be noted that compound $\mathbf{1 8}$ exhibited more than $70 \%$ inhibition at the doses of 10 , 20 and $40 \mathrm{mg} / \mathrm{kg}$, which was equivalent to acetylsalicylic acid. To further investigate the antinociceptive profile of compounds 10-28, a hot plate test was then conducted. Compounds 10, 18 and 19 increased latency by $191.5 \%, 116.0 \%$ and $134.4 \%$, respectively, while compounds 11, 14, 15, 20, 24 and 25 showed negative results in the hot plate test (Table 1).

Table 1. Antinociceptive effect of final compounds in the writhing test and hot plate test.

\begin{tabular}{|c|c|c|c|c|c|c|c|c|}
\hline \multirow[t]{2}{*}{ Compound $^{\mathrm{a}}$} & \multirow[t]{2}{*}{ Ar } & \multirow[t]{2}{*}{$\mathbf{R}$} & \multirow{2}{*}{$\begin{array}{c}\text { Dose } \\
(\mathrm{mg} / \mathrm{kg})\end{array}$} & \multicolumn{3}{|c|}{ Licking latency (s) ${ }^{\text {b }}$} & \multicolumn{2}{|c|}{ Writhing } \\
\hline & & & & $\begin{array}{c}\text { Before } \\
\text { treatment }\end{array}$ & $\begin{array}{c}\text { After } \\
\text { treatment } \\
(60 \mathrm{~min})\end{array}$ & $\begin{array}{c}\text { Increased } \\
\text { rate of } \\
\text { latency } \\
(\%) \\
\end{array}$ & $\begin{array}{c}\text { Writhes } \\
\text { (per } 15 \\
\text { min) }\end{array}$ & $\begin{array}{c}\text { Inhibition } \\
(\%)\end{array}$ \\
\hline \multirow[t]{3}{*}{10} & $2-\mathrm{OCH}_{3}-\mathrm{Ph}$ & - & 10 & $14.1 \pm 1.3$ & $29.0 \pm 0.9 *$ & 105.7 & $12.1 \pm 1.1$ & 43.3 \\
\hline & & & 20 & $13.0 \pm 0.9$ & $37.9 \pm 1.3 *$ & 191.5 & $13.2 \pm 3.9$ & 38.0 \\
\hline & & & 40 & $13.7 \pm 1.5$ & $29.4 \pm 1.5 *$ & 114.6 & $6.4 \pm 2.2 * *$ & 70.0 \\
\hline \multirow[t]{3}{*}{11} & $3-\mathrm{OCH}_{3}-\mathrm{Ph}$ & - & 10 & $15.5 \pm 0.6$ & $16.7 \pm 2.1$ & 7.7 & $7.2 \pm 3.6 *$ & 66.4 \\
\hline & & & 20 & $17.3 \pm 0.9$ & $19.0 \pm 1.2$ & 9.8 & $24.4 \pm 9.9$ & -14.5 \\
\hline & & & 40 & $18.4 \pm 1.3$ & $27.4 \pm 4.3$ & 48.9 & $4.9 \pm 1.3 *$ & 77.1 \\
\hline \multirow[t]{3}{*}{12} & $4-\mathrm{OCH}_{3}-\mathrm{Ph}$ & - & 10 & $18.3 \pm 1.2$ & $14.0 \pm 0.8$ & -23.5 & $17.9 \pm 4.2$ & 15.8 \\
\hline & & & 20 & $14.5 \pm 1.5$ & $17.0 \pm 1.2$ & 17.2 & $19.7 \pm 2.8$ & 7.3 \\
\hline & & & 40 & $12.4 \pm 1.4$ & $22.0 \pm 0.9$ & 77.4 & $20.2 \pm 2.9$ & 5.0 \\
\hline \multirow[t]{3}{*}{13} & 2-Cl-Ph & - & 10 & $15.6 \pm 1.2$ & $18.4 \pm 1.6$ & 17.9 & $11.9 \pm 2.7$ & 44.3 \\
\hline & & & 20 & $19.9 \pm 1.3$ & $20.2 \pm 2.1$ & 1.5 & $14.8 \pm 3.6$ & 30.5 \\
\hline & & & 40 & $15.2 \pm 2.1$ & $17.6 \pm 2.3$ & 15.8 & $13.0 \pm 4.4$ & 38.9 \\
\hline \multirow[t]{3}{*}{14} & 3-Cl-Ph & - & 10 & $15.9 \pm 1.6$ & $13.9 \pm 1.2$ & -12.6 & $9.6 \pm 3.8$ & 55.0 \\
\hline & & & 20 & $20.2 \pm 2.1$ & $23.1 \pm 1.3$ & 14.3 & $7.2 \pm 3.4 *$ & 66.4 \\
\hline & & & 40 & $18.1 \pm 0.9$ & $25.3 \pm 2.3$ & 39.8 & $6.3 \pm 2.2 *$ & 70.2 \\
\hline \multirow[t]{3}{*}{15} & 4-Cl-Ph & - & 10 & $16.0 \pm 1.7$ & $15.8 \pm 2.3$ & -1.3 & $5.5 \pm 1.3 *$ & 74.1 \\
\hline & & & 20 & $15.5 \pm 1.6$ & $22.1 \pm 1.3$ & 42.6 & $8.9 \pm 1.0$ & 58.0 \\
\hline & & & 40 & $18.9 \pm 1.4$ & $27.1 \pm 3.4$ & 43.4 & $3.7 \pm 1.5 *$ & 82.4 \\
\hline \multirow[t]{3}{*}{16} & 2,3-di-Cl-Ph & - & 10 & $17.4 \pm 1.3$ & $17.9 \pm 1.8$ & 2.9 & $9.8 \pm 3.6$ & 54.1 \\
\hline & & & 20 & $19.5 \pm 1.5$ & $23.3 \pm 2.1$ & 19.5 & $12.2 \pm 2.6$ & 42.6 \\
\hline & & & 40 & $18.3 \pm 1.6$ & $26.6 \pm 3.9$ & 45.4 & $28.6 \pm 6.6$ & -34.4 \\
\hline \multirow[t]{3}{*}{17} & 4-F-Ph & - & 10 & $15.5 \pm 1.8$ & $17.3 \pm 0.9$ & 11.6 & $32.3 \pm 3.2$ & -51.8 \\
\hline & & & 20 & $17.3 \pm 1.9$ & $23.7 \pm 1.5$ & 37.0 & $25.2 \pm 5.7$ & -18.3 \\
\hline & & & 40 & $18.4 \pm 2.1$ & $19.8 \pm 2.6$ & 7.6 & $27.5 \pm 2.9$ & -29.2 \\
\hline
\end{tabular}


Table 1. Cont.

\begin{tabular}{|c|c|c|c|c|c|c|c|c|}
\hline 18 & $3-\mathrm{CF}_{3}-\mathrm{Ph}$ & - & $\begin{array}{l}10 \\
20 \\
40\end{array}$ & $\begin{array}{l}17.6 \pm 1.3 \\
19.2 \pm 2.4 \\
16.2 \pm 2.3\end{array}$ & $\begin{array}{c}27.5 \pm 2.6 \\
39.8 \pm 2.4 * \\
35.0 \pm 3.1 *\end{array}$ & $\begin{array}{l}56.3 \\
107.3 \\
116.0 \\
\end{array}$ & $\begin{array}{l}5.8 \pm 2.0 * \\
5.3 \pm 1.5 * \\
4.5 \pm 1.4 *\end{array}$ & $\begin{array}{l}73.0 \\
75.2 \\
78.7 \\
\end{array}$ \\
\hline 19 & 2,3-di- $\mathrm{CH}_{3}-\mathrm{Ph}$ & - & $\begin{array}{l}10 \\
20 \\
40 \\
\end{array}$ & $\begin{array}{l}19.3 \pm 1.3 \\
15.7 \pm 1.4 \\
16.3 \pm 2.3 \\
\end{array}$ & $\begin{array}{l}26.6 \pm 3.6 \\
33.2 \pm 1.8 * \\
38.2 \pm 2.1 *\end{array}$ & $\begin{array}{l}37.8 \\
111.5 \\
134.4 \\
\end{array}$ & $\begin{array}{l}5.3 \pm 2.0 * \\
7.7 \pm 2.2 * \\
10.3 \pm 3.2\end{array}$ & $\begin{array}{l}75.2 \\
63.7 \\
51.8 \\
\end{array}$ \\
\hline 20 & $\begin{array}{l}\text { 6-methoxy- } \\
\text { benzo[d]- } \\
\text { thiazole }\end{array}$ & - & $\begin{array}{l}10 \\
20 \\
40 \\
\end{array}$ & $\begin{array}{l}19.6 \pm 2.8 \\
16.9 \pm 1.6 \\
18.0 \pm 1.9 \\
\end{array}$ & $\begin{array}{l}21.0 \pm 2.3 \\
18.1 \pm 2.4 \\
26.4 \pm 3.1 \\
\end{array}$ & $\begin{array}{l}7.1 \\
7.1 \\
46.7 \\
\end{array}$ & $\begin{array}{l}6.9 \pm 2.0 * \\
11.2 \pm 3.3 \\
7.3 \pm 1.8 *\end{array}$ & $\begin{array}{l}67.6 \\
47.2 \\
65.7 \\
\end{array}$ \\
\hline 21 & $\begin{array}{l}\text { 6-methyl- } \\
\text { benzo[d]- } \\
\text { thiazole }\end{array}$ & - & $\begin{array}{l}10 \\
20 \\
40 \\
\end{array}$ & $\begin{array}{l}18.7 \pm 1.6 \\
17.6 \pm 2.8 \\
16.2 \pm 2.3\end{array}$ & $\begin{array}{l}19.1 \pm 3.1 \\
16.3 \pm 1.5 \\
24.1 \pm 1.6\end{array}$ & $\begin{array}{l}2.1 \\
-7.4 \\
48.8 \\
\end{array}$ & $\begin{array}{l}11.4 \pm 2.4 \\
15.9 \pm 4.8 \\
9.3 \pm 5.7\end{array}$ & $\begin{array}{l}46.3 \\
25.9 \\
56.5 \\
\end{array}$ \\
\hline 22 & $\begin{array}{l}\text { 4-methyl- } \\
\text { benzo[d]- } \\
\text { thiazole }\end{array}$ & - & $\begin{array}{l}10 \\
20 \\
40 \\
\end{array}$ & $\begin{array}{l}15.0 \pm 1.3 \\
15.9 \pm 3.1 \\
18.5 \pm 1.8 \\
\end{array}$ & $\begin{array}{l}21.9 \pm 2.1 \\
17.1 \pm 2.6 \\
22.5 \pm 2.4\end{array}$ & $\begin{array}{l}46.0 \\
7.5 \\
21.6 \\
\end{array}$ & $\begin{array}{l}32.5 \pm 6.1 \\
12.6 \pm 3.7 \\
9.5 \pm 4.2\end{array}$ & $\begin{array}{l}-52.8 \\
40.7 \\
55.6 \\
\end{array}$ \\
\hline 23 & $\begin{array}{l}\text { 6-chloro- } \\
\text { benzo[d]- } \\
\text { thiazole }\end{array}$ & - & $\begin{array}{l}10 \\
20 \\
40 \\
\end{array}$ & $\begin{array}{l}16.3 \pm 1.3 \\
18.5 \pm 1.8 \\
20.6 \pm 1.9\end{array}$ & $\begin{array}{l}24.9 \pm 1.9 \\
26.2 \pm 3.8 \\
25.0 \pm 2.6\end{array}$ & $\begin{array}{l}52.8 \\
41.6 \\
5.9 \\
\end{array}$ & $\begin{array}{l}15.4 \pm 6.3 \\
33.7 \pm 5.7 \\
13.0 \pm 4.3\end{array}$ & $\begin{array}{l}27.8 \\
-58.3 \\
38.9 \\
\end{array}$ \\
\hline 24 & $\begin{array}{l}\text { 4-chloro- } \\
\text { benzo[d]- } \\
\text { thiazole }\end{array}$ & - & $\begin{array}{l}10 \\
20 \\
40 \\
\end{array}$ & $\begin{array}{l}18.6 \pm 2.1 \\
17.5 \pm 1.3 \\
16.1 \pm 1.7 \\
\end{array}$ & $\begin{array}{l}28.5 \pm 1.0 * \\
28.6 \pm 0.6 * \\
22.4 \pm 2.5\end{array}$ & $\begin{array}{l}53.2 \\
63.4 \\
39.1 \\
\end{array}$ & $\begin{array}{l}5.8 \pm 2.1 * \\
21.5 \pm 5.9 \\
37.3 \pm 9.1 \\
\end{array}$ & $\begin{array}{l}75.2 \\
-0.9 \\
-75.0 \\
\end{array}$ \\
\hline 25 & 2-pyrimidine & - & $\begin{array}{l}10 \\
20 \\
40 \\
\end{array}$ & $\begin{array}{l}17.3 \pm 1.8 \\
15.3 \pm 2.0 \\
20.3 \pm 1.6 \\
\end{array}$ & $\begin{array}{l}24.5 \pm 3.7 \\
15.1 \pm 1.9 \\
24.7 \pm 1.8 \\
\end{array}$ & $\begin{array}{l}41.6 \\
-1.3 \\
21.7 \\
\end{array}$ & $\begin{array}{l}11.2 \pm 3.4 \\
8.0 \pm 2.1 \\
7.6 \pm 5.2 * \\
\end{array}$ & $\begin{array}{l}47.3 \\
43.9 \\
64.2 \\
\end{array}$ \\
\hline 26 & $4-\mathrm{OCH}_{3}-\mathrm{Ph}$ & $\mathrm{H}$ & $\begin{array}{l}10 \\
20 \\
40 \\
\end{array}$ & $\begin{array}{l}13.0 \pm 1.9 \\
11.4 \pm 2.4 \\
17.4 \pm 1.3 \\
\end{array}$ & $\begin{array}{l}16.6 \pm 2.1 \\
19.1 \pm 1.6 \\
23.8 \pm 1.7 \\
\end{array}$ & $\begin{array}{l}27.7 \\
67.5 \\
36.8 \\
\end{array}$ & $\begin{array}{l}38.7 \pm 6.6 \\
43.7 \pm 5.1 \\
25.8 \pm 7.7 \\
\end{array}$ & $\begin{array}{l}-81.6 \\
-105.3 \\
-21.1 \\
\end{array}$ \\
\hline 27 & $2-\mathrm{OCH}_{3}-\mathrm{Ph}$ & $\mathrm{H}$ & $\begin{array}{l}10 \\
20 \\
40 \\
\end{array}$ & $\begin{array}{l}18.9 \pm 2.4 \\
15.0 \pm 2.3 \\
13.8 \pm 1.8 \\
\end{array}$ & $\begin{array}{l}25.4 \pm 2.1 \\
20.6 \pm 1.6 \\
21.9 \pm 1.4 \\
\end{array}$ & $\begin{array}{l}34.4 \\
37.3 \\
58.7 \\
\end{array}$ & $\begin{array}{l}29.2 \pm 9.9 \\
23.3 \pm 6.4 \\
11.7 \pm 3.1 \\
\end{array}$ & $\begin{array}{l}-37.1 \\
-9.4 \\
45.1 \\
\end{array}$ \\
\hline 28 & $2-\mathrm{OCH}_{3}-\mathrm{Ph}$ & $\begin{array}{l}\mathrm{C}_{2} \mathrm{H} \\
5\end{array}$ & $\begin{array}{l}10 \\
20 \\
40 \\
\end{array}$ & $\begin{array}{l}17.0 \pm 1.5 \\
19.0 \pm 1.5 \\
17.6 \pm 1.4 \\
\end{array}$ & $\begin{array}{l}24.1 \pm 2.3 \\
27.3 \pm 4.8 \\
26.4 \pm 1.3 \\
\end{array}$ & $\begin{array}{l}45.3 \\
43.7 \\
50.0 \\
\end{array}$ & $\begin{array}{l}16.4 \pm 3.3 \\
11.1 \pm 2.4 \\
34.5 \pm 10.2 \\
\end{array}$ & $\begin{array}{l}22.9 \\
47.8 \\
-62.2 \\
\end{array}$ \\
\hline saline & - & - & - & $16.4 \pm 2.3$ & $19.2 \pm 1.8$ & 17.1 & $21.3 \pm 3.7$ & - \\
\hline $\begin{array}{l}\text { acetylsalicylic } \\
\text { acid }\end{array}$ & - & - & 100 & - & - & - & $5.2 \pm 0.3 * *$ & 75.6 \\
\hline morphine & - & - & 5 & $15.4 \pm 1.6$ & $36.3 \pm 2.1 *$ & 135.7 & - & \\
\hline
\end{tabular}

${ }^{a}$ Compound and acetylsalicylic acid were administered orally, morphine were administered subcutaneously;

${ }^{\mathrm{b}}$ Measured at $55.5^{\circ} \mathrm{C}$ as licking latency (s) at various times after treatment; $* P<0.05, * * P<0.01$.

\subsection{Acute Toxicity}

Therefore, considering the results from compounds 10-28, we concluded that compounds 10,18 and 19 showed more potent analgesic activity. We then assayed the acute toxicity of the compounds by determining their $\mathrm{LD}_{50}$ values (Table 2) [23]. Compounds 18 and 19 showed good safety profiles, even 
at the highest dose. No convulsions or tremors were detected in mice, during the $24 \mathrm{~h}$ observation. However, compound $\mathbf{1 0}$ showed side effects with the highest dose.

Table 2. Acute toxicity $\mathrm{LD}_{50}$ of the compounds.

\begin{tabular}{ll}
\hline Compound $^{\text {a }}$ & LD $_{\mathbf{5 0}}(\mathbf{m g} / \mathbf{k g})$ \\
\hline 10 & $477.0(357.2-637.1)$ \\
18 & $>2,000$ \\
19 & $>2,000$ \\
\hline \multicolumn{2}{c}{${ }^{a}$ Compounds were administered orally. }
\end{tabular}

\subsection{Exploratory Locomotor Activity}

Compounds that cause sedation will result in a reduction in spontaneous exploratory locomotor activity [24]. Pretreatment with 40, 80 and $160 \mathrm{mg} / \mathrm{kg}$ of compounds $\mathbf{1 8}$ and $\mathbf{1 9}$ did not reduce exploratory locomotor activity (Table 3). In comparison, clonazepam significantly reduced spontaneous locomotor activity.

Table 3. Effects of compounds on exploratory locomotors activity.

\begin{tabular}{|c|c|c|c|c|c|c|}
\hline \multirow{3}{*}{ Compound } & \multirow{3}{*}{$\begin{array}{l}\text { Dose } \\
\text { (mg/kg, } \\
\text { po) }\end{array}$} & \multicolumn{5}{|c|}{ Average speed $(\mathrm{cm} / \mathrm{s})$} \\
\hline & & \multirow{2}{*}{$\begin{array}{l}\text { Before } \\
\text { treatment }\end{array}$} & \multicolumn{4}{|c|}{ After treatment } \\
\hline & & & $30 \mathrm{~min}$ & $60 \mathrm{~min}$ & $90 \mathrm{~min}$ & $120 \mathrm{~min}$ \\
\hline Control & - & $8.48 \pm 3.02$ & $7.95 \pm 2.85$ & $7.64 \pm 2.94$ & $7.09 \pm 2.89$ & $7.98 \pm 2.89$ \\
\hline clonazepam & 15 & $7.42 \pm 2.62$ & $3.28 \pm 2.03 * *$ & $3.16 \pm 2.32 * *$ & $3.41 \pm 3.75 * *$ & $2.99 \pm 1.89 * *$ \\
\hline \multirow{3}{*}{18} & 40 & $8.56 \pm 2.89$ & $7.94 \pm 2.50$ & $7.75 \pm 1.72$ & $7.51 \pm 1.74$ & $7.88 \pm 3.01$ \\
\hline & 80 & $7.63 \pm 1.9$ & $7.54 \pm 3.05$ & $7.03 \pm 3.55$ & $7.75 \pm 2.95$ & $7.46 \pm 2.47$ \\
\hline & 160 & $7.49 \pm 2.51$ & $7.94 \pm 2.72$ & $7.56 \pm 3.65$ & $7.47 \pm 2.17$ & $6.98 \pm 2.27$ \\
\hline \multirow{3}{*}{19} & 40 & $7.16 \pm 2.07$ & $6.75 \pm 3.95$ & $6.71 \pm 2.02$ & $5.62 \pm 2.40$ & $5.64 \pm 3.13$ \\
\hline & 80 & $8.36 \pm 3.23$ & $7.83 \pm 3.40$ & $6.82 \pm 3.26$ & $7.44 \pm 2.61$ & $7.68 \pm 2.43$ \\
\hline & 160 & $8.12 \pm 2.61$ & $6.36 \pm 3.00$ & $6.81 \pm 2.84$ & $6.88 \pm 3.05$ & $6.55 \pm 2.99$ \\
\hline
\end{tabular}

${ }^{a}$ Compound and clonazepam were administered orally; each value represents the mean of 10 mice;

$* \mathrm{P}<0.01, * \mathrm{P}<0.05$ vs. before treatment.

Preliminarily, compounds were screened by both the writhing and hot plate tests at doses of 10, 20 and $40 \mathrm{mg} / \mathrm{kg}$. Then, the compound with minimal toxicity base on the $\mathrm{LD}_{50}$ values was found. In addition, in order to examine the effect of synthesized compounds in the treatment of neuropathic pain, we refer to the dose of gabapentin (orally dose $40 \mathrm{mg} / \mathrm{kg}$ ) [25-27].

\subsection{Formalin Test}

The analgesic activity of compounds $\mathbf{1 8}$ and $\mathbf{1 9}$ were further investigated by the formalin test [28]. Compound 18 could significantly reduce pain responses compared to control groups in both phases at the dose of 80 and $160 \mathrm{mg} / \mathrm{kg}$, whereas 19 was devoid of any efficacy in both phases (Figure $2 \mathrm{~A}, \mathrm{~B}$ ). 


\subsection{Spared Nerve Injury (SNI) and Chronic Constriction Injury (CCI) Test}

Currently available drugs for treating neuropathic pain are typically undesirable because of their intolerable side effects [8]. For example, gabapentin [1-(aminomethyl)cyclohexaneacetic acid] is considered to be the "gold standard" for a variety of neuropathic pains [28], but its efficacy is usually less than 50\% [30], and it's known to induce sedation at high doses [28]. To examine the potential therapeutic value of compounds 18 and 19 in the treatment of neuropathic pain, two well-known peripheral neuropathic pain models were investigated, including the spared nerve injury (SNI) [31] and chronic constriction injury (CCI) [32] models in rats.

Figure 2. Effects of $\mathbf{1 8}$ and $\mathbf{1 9}$ administered po and morphine (ip) on the pain in rat. (A) the first phase (0-5 $\mathrm{min})$; (B) the second phase (15-60 $\mathrm{min})$. Each column represents mean \pm S.E.M. of ten experimental values. * In comparison to the control group. * $\mathrm{P}<0.05 ; * * \mathrm{P}<0.01$.

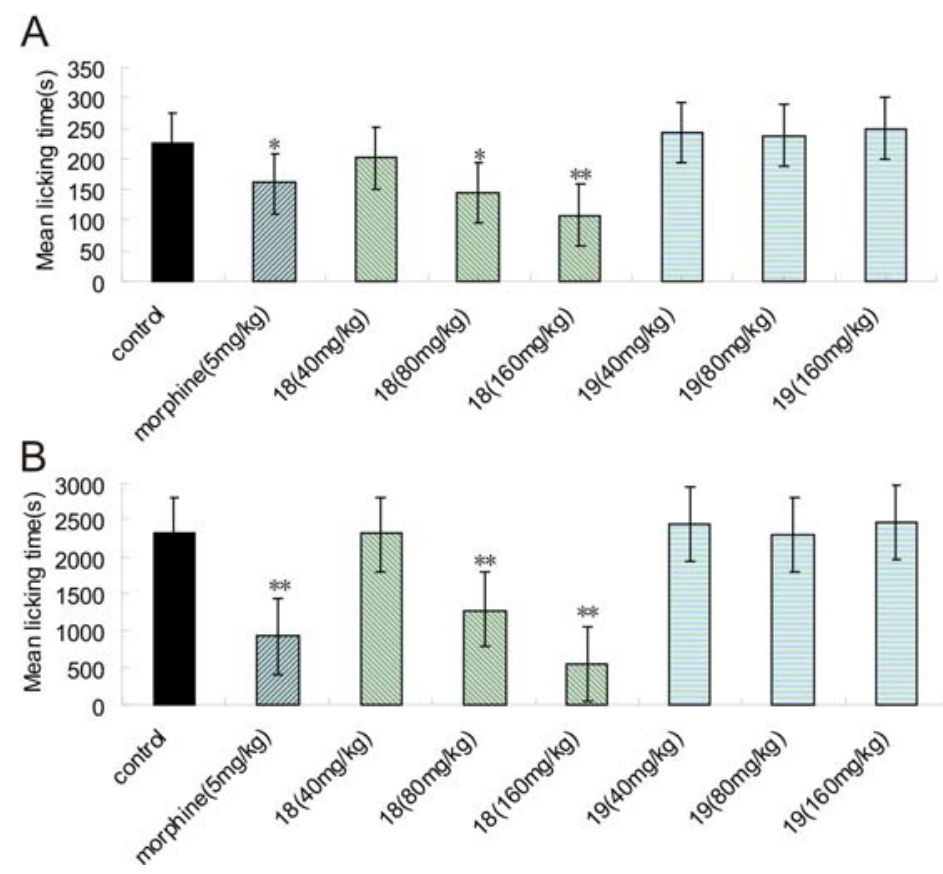

In the SNI model, compound $18(80,160 \mathrm{mg} / \mathrm{kg})$ significantly increased the mechanical allodynia when treated with single and repeated dose treatment $(p<0.05)$. After 13 days, compound 18 increased the pain threshold by $33.2 \%(80 \mathrm{mg} / \mathrm{kg})$ and $40.4 \%(160 \mathrm{mg} / \mathrm{kg})$ with single dose treatment, and by $29.6 \%(80 \mathrm{mg} / \mathrm{kg})$ and $32.8 \%(160 \mathrm{mg} / \mathrm{kg})$ with repeated dose treatment. In comparison, gabapentin increased the pain threshold by $33.7 \%$ and $42.7 \%$, respectively (Table 4 ). These results suggested that the pain response inhibition of compound 18 was equivalent to that of gabapentin.

In the mechanical stimulation of CCI model, compound $18(80 \mathrm{mg} / \mathrm{kg})$ could significantly improve the mechanical allodynia in comparison to the model group with single and repeated dose treatment $(\mathrm{p}<0.05)$. Compound $19(80 \mathrm{mg} / \mathrm{kg})$ only improved the mechanical allodynia with single dose treatment. After 13 days, compound 18 and gabapentin both significantly increased the pain threshold (Table 5). 
Table 4. Effects of compounds on mechanical allodynia in the SNI model.

\begin{tabular}{|c|c|c|c|c|c|c|}
\hline \multirow[b]{2}{*}{ Compound } & \multirow[b]{2}{*}{$\begin{array}{c}\text { Dose } \\
(\mathrm{mg} / \mathrm{kg}, \\
\text { po) }\end{array}$} & \multirow[b]{2}{*}{$\begin{array}{c}\text { Number } \\
\text { of rats }\end{array}$} & \multicolumn{4}{|c|}{ Mechanical allodynia (g) } \\
\hline & & & Baseline & \begin{tabular}{l}
\multicolumn{1}{c}{ Before } \\
administration \\
(decreased rate \\
of pain \\
threshold $\%$ ) $^{\text {a }}$ \\
\end{tabular} & $\begin{array}{l}\text { Single administration } \\
\text { (increased rate of }^{c} \\
\text { pain threshold \%) }^{b}\end{array}$ & $\begin{array}{l}\text { Repeated administration } \\
\text { (increased rate of } \\
\text { pain threshold \%) }\end{array}$ \\
\hline \multirow{2}{*}{ Sham } & \multirow{2}{*}{-} & \multirow{2}{*}{10} & \multirow{2}{*}{$55.1 \pm 4.4$} & $49.7 \pm 12.4 * *$ & $48.1 \pm 11.1 * *$ & $55.8 \pm 8.6 * *$ \\
\hline & & & & 9.7 & -3.3 & 12.3 \\
\hline \multirow{2}{*}{ Control } & \multirow{2}{*}{ - } & \multirow{2}{*}{10} & \multirow{2}{*}{$61.86 \pm 5.48$} & $29.7 \pm 4.3^{\#}$ & $30.9 \pm 4.8^{\# \#}$ & $28.7 \pm 3.8^{\#}$ \\
\hline & & & & 52.0 & 3.9 & -3.2 \\
\hline \multirow{2}{*}{ Gabapentin } & \multirow{2}{*}{40} & \multirow{2}{*}{10} & \multirow{2}{*}{$60.9 \pm 5.6$} & $28.5 \pm 5.3^{\#}$ & $38.1 \pm 5.4 *$ & $40.6 \pm 7.9^{* *}$ \\
\hline & & & & 53.3 & 33.7 & 42.7 \\
\hline \multirow{6}{*}{18} & \multirow{2}{*}{40} & \multirow{2}{*}{10} & \multirow{2}{*}{$60.3 \pm 6.0$} & $28.7 \pm 4.1^{\# \#}$ & $35.2 \pm 8.6$ & $30.5 \pm 8.5$ \\
\hline & & & & 52.3 & 22.3 & 5.9 \\
\hline & \multirow{2}{*}{80} & \multirow{2}{*}{10} & \multirow{2}{*}{$60.8 \pm 3.2$} & $28.4 \pm 3.6^{\#}$ & $37.8 \pm 5.5 *$ & $36.8 \pm 4.8 *$ \\
\hline & & & & 53.3 & 33.2 & 29.6 \\
\hline & \multirow{2}{*}{160} & \multirow{2}{*}{10} & \multirow{2}{*}{$63.4 \pm 4.2$} & $28.7 \pm 5.1{ }^{\#}$ & $40.3 \pm 5.4 * *$ & $38.1 \pm 8.5 *$ \\
\hline & & & & 54.7 & 40.4 & 32.8 \\
\hline \multirow{6}{*}{19} & \multirow{2}{*}{40} & \multirow{2}{*}{10} & \multirow{2}{*}{$61.8 \pm 5.8$} & $28.4 \pm 7.2^{\#}$ & $32.9 \pm 9.1$ & $34.5 \pm 2.3$ \\
\hline & & & & 54.1 & 15.8 & 21.6 \\
\hline & \multirow{2}{*}{80} & \multirow{2}{*}{10} & \multirow{2}{*}{$55.3 \pm 13.3$} & $29.0 \pm 5.4^{\#}$ & $33.9 \pm 8.2$ & $30.2 \pm 6.7$ \\
\hline & & & & 47.5 & 16.7 & 4.0 \\
\hline & \multirow{2}{*}{160} & \multirow{2}{*}{10} & \multirow{2}{*}{$58.8 \pm 5.8$} & $28.3 \pm 5.6^{\#}$ & $30.0 \pm 5.4$ & $33.1 \pm 3.3$ \\
\hline & & & & 51.8 & 5.8 & 16.8 \\
\hline
\end{tabular}

${ }^{\#} \mathrm{p}<0.05 ;{ }^{\#} \mathrm{p}<0.01$ vs. baseline; * $\mathrm{p}<0.05 ; * * \mathrm{p}<0.01$ vs. control.

${ }^{\mathrm{a}}$ Decreased rate of pain threshold $(\%)=$ (pain threshold of 13 th day-pain threshold of baseline) $\times 100 \% /$ pain threshold of baseline.

b Increased rate of pain threshold $(\%)=$ (pain threshold of after administration-pain threshold of before administration) $\times 100 \%$ / pain threshold of before administration.

${ }^{c}$ Each group was measured after first administration on the 14th day and the last administration on the 17th day, which was the result of single administration and repeated administration, respectively.

Table 5. Effects of compounds on mechanical allodynia in the CCI model.

\begin{tabular}{|c|c|c|c|c|c|c|}
\hline \multirow[b]{2}{*}{ Compound } & \multirow[b]{2}{*}{$\begin{array}{l}\text { Dose } \\
(\mathrm{mg} / \mathrm{kg} \text {, } \\
\text { po) }\end{array}$} & \multirow[b]{2}{*}{$\begin{array}{l}\text { Number } \\
\text { of rats }\end{array}$} & \multicolumn{4}{|c|}{ Mechanical allodynia (g) } \\
\hline & & & Baseline & $\begin{array}{l}\text { Before } \\
\text { administration } \\
\text { (decreased } \\
\text { rate of pain } \\
\text { threshold \%) }\end{array}$ & 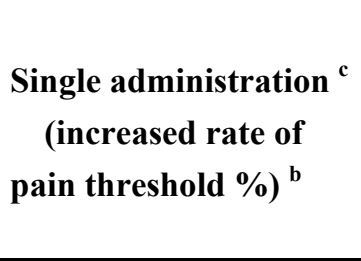 & 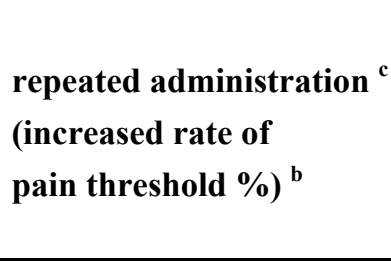 \\
\hline sham & - & 10 & $56.0 \pm 5.9$ & $\begin{array}{l}51.2 \pm 9.0 * * \\
8.7\end{array}$ & $\begin{array}{l}53.4 \pm 9.8 * * \\
4.4\end{array}$ & $\begin{array}{l}49.0 \pm 7.3 * * \\
-4.2\end{array}$ \\
\hline control & - & 10 & $58.3 \pm 6.7$ & $\begin{array}{l}31.25 \pm 5.1 \\
46.5\end{array}$ & $\begin{array}{l}31.8 \pm 5.5^{\# \#} \\
2.1\end{array}$ & $\begin{array}{l}31.7 \pm 6.4^{\# \#} \\
1.73\end{array}$ \\
\hline
\end{tabular}


Table 5. Cont.

\begin{tabular}{|c|c|c|c|c|c|c|}
\hline \multirow{2}{*}{ Gabapentin } & \multirow{2}{*}{40} & \multirow{2}{*}{10} & \multirow{2}{*}{$59.44 \pm 6.20$} & $31.4 \pm 4.4^{\# \#}$ & $39.1 \pm 4.9^{* *}$ & $37.3 \pm 7.5 *$ \\
\hline & & & & 47.2 & 24.6 & 18.7 \\
\hline \multirow{6}{*}{18} & \multirow{2}{*}{40} & \multirow{2}{*}{10} & \multirow{2}{*}{$56.7 \pm 4.7$} & $34.1 \pm 2.4^{\# \#}$ & $36.2 \pm 4.8$ & $33.6 \pm 6.7$ \\
\hline & & & & 39.9 & 6.3 & -1.5 \\
\hline & \multirow{2}{*}{80} & \multirow{2}{*}{10} & \multirow{2}{*}{$58.7 \pm 8.2$} & $31.9 \pm 3.5^{\text {\#\# }}$ & $37.5 \pm 8.3 *$ & $38.0 \pm 6.2 *$ \\
\hline & & & & 45.68 & 17.6 & 19.2 \\
\hline & \multirow{2}{*}{160} & \multirow{2}{*}{10} & \multirow{2}{*}{$59.0 \pm 4.4$} & $32.1 \pm 6.0^{\# \#}$ & $35.9 \pm 6.5$ & $32.9 \pm 4.0$ \\
\hline & & & & 45.6 & 11.9 & 2.6 \\
\hline \multirow{6}{*}{19} & \multirow{2}{*}{40} & \multirow{2}{*}{10} & \multirow{2}{*}{$61.6 \pm 4.9$} & $31.3 \pm 3.4$ \#\# & $32.9 \pm 2.7$ & $33.4 \pm 3.4$ \\
\hline & & & & 49.2 & 5.1 & 6.9 \\
\hline & \multirow{2}{*}{80} & \multirow{2}{*}{10} & \multirow{2}{*}{$56.4 \pm 5.6$} & $31.1 \pm 4.8^{\# \#}$ & $37.1 \pm 3.5 *$ & $32.0 \pm 4.7$ \\
\hline & & & & 44.9 & 19.3 & 2.8 \\
\hline & \multirow{2}{*}{160} & \multirow{2}{*}{10} & \multirow{2}{*}{$59.6 \pm 5.2$} & $31.1 \pm 4.6^{\# \#}$ & $32.1 \pm 3.2$ & $29.8 \pm 7.2$ \\
\hline & & & & 47.8 & 3.2 & -4.3 \\
\hline
\end{tabular}

${ }^{\#} \mathrm{p}<0.05 ;{ }^{\# \#} \mathrm{p}<0.01$ vs. baseline; * $\mathrm{p}<0.05 ; * * \mathrm{p}<0.01$ vs. control.

${ }^{a}$ Decreased rate of pain threshold $(\%)=$ (pain threshold of 13th day-pain threshold of baseline) $\times 100 \% /$ pain threshold of baseline.

b Increased rate of pain threshold $(\%)=$ (pain threshold of after administration-pain threshold of before administration) $\times 100 \% /$ pain threshold of before administration.

${ }^{\mathrm{c}}$ Each group was measured after first administration on the 14th day and the last administration on the 17th day, which was the result of single administration and repeated administration, respectively.

In the thermal stimulation of the CCI model, compound 18 increased the latency when treated with single and repeated doses $(\mathrm{p}<0.05)$. After 13 days, compound $18(40 \mathrm{mg} / \mathrm{kg})$ increased latency by $53.5 \%$ and $66.4 \%$ with single and repeated dose treatment, significantly higher than the effectiveness of gabapentin (Table 6).

Overall, compound $\mathbf{1 8}$ yielded high effectiveness in both the CCI and SNI model. Results also suggested that compound 18 was suitable for the treatment of neuropathic pain, which was equivalent to gabapentin without inducing severe sedative side effect.

Table 6. Effects of compounds on latency of thermal stimulation in the CCI model.

\begin{tabular}{|c|c|c|c|c|c|c|}
\hline \multirow[b]{2}{*}{ Compound } & \multirow[b]{2}{*}{$\begin{array}{l}\text { Dose } \\
(\mathrm{mg} / \mathrm{kg} \text {, } \\
\text { po) }\end{array}$} & \multirow[b]{2}{*}{$\begin{array}{l}\text { Number } \\
\text { of rats }\end{array}$} & \multicolumn{4}{|c|}{ Latency (s) } \\
\hline & & & Baseline & $\begin{array}{l}\text { Before } \\
\text { administration } \\
\text { (decreased rate } \\
\text { of latency \%) }\end{array}$ & $\begin{array}{c}\text { Single administration } \\
{ }^{c} \\
\text { (increased rate of } \\
\text { latency } \%)^{b}\end{array}$ & $\begin{array}{l}\text { Repeated administration } \\
\text { (increased rate of } \\
\text { latency } \%)^{b}\end{array}$ \\
\hline Sham & - & 10 & $14.7 \pm 2.9$ & $\begin{array}{l}13.2 \pm 2.7 * \\
9.9\end{array}$ & $\begin{array}{l}13.41 \pm 3.4 * \\
1.4\end{array}$ & $\begin{array}{l}14.2 \pm 4.1 * \\
7.2\end{array}$ \\
\hline Control & - & 10 & $15.1 \pm 2.9$ & $\begin{array}{l}10.2 \pm 3.1 \\
32.5\end{array}$ & $\begin{array}{l}10.4 \pm 3.4^{\# \#} \\
2.5\end{array}$ & $\begin{array}{l}11.2 \pm 3.3^{\# \#} \\
9.5\end{array}$ \\
\hline Gabapentin & 40 & 10 & $15.7 \pm 3.6$ & $\begin{array}{l}11.9 \pm 3.5^{\#} \\
24.6\end{array}$ & $\begin{array}{l}17.9 \pm 7.6 * * \\
50.5\end{array}$ & $\begin{array}{l}17.0 \pm 13.9 \\
42.9\end{array}$ \\
\hline
\end{tabular}


Table 6. Cont.

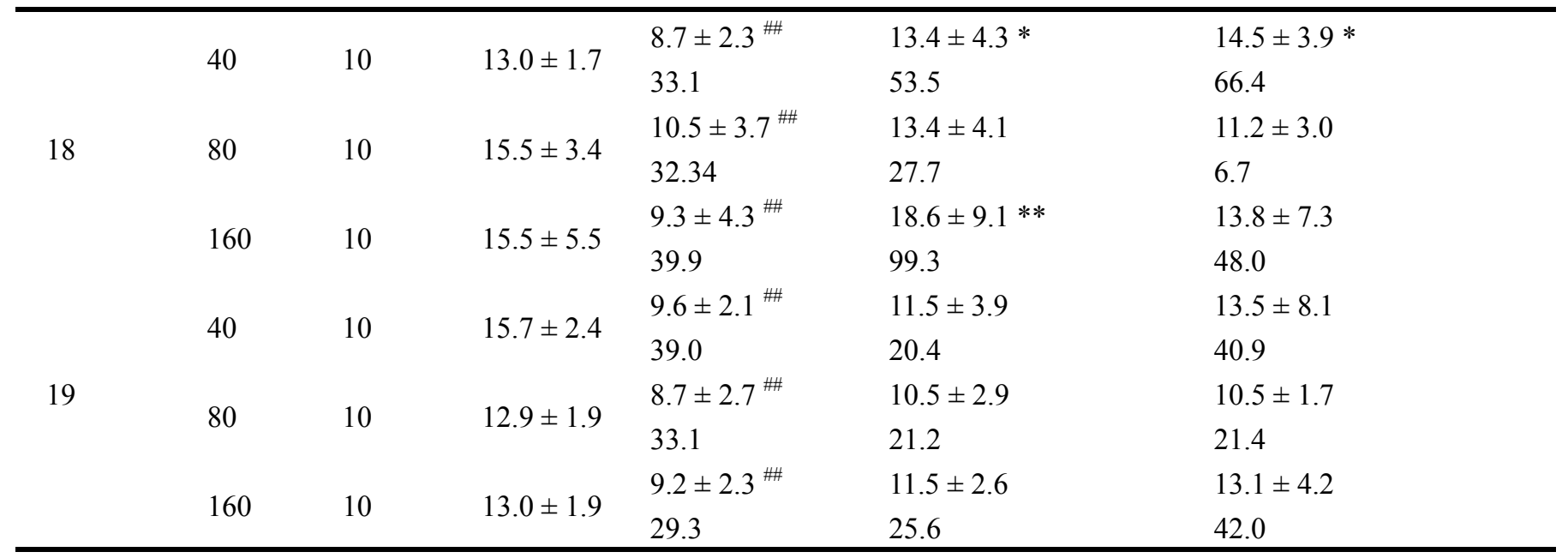

${ }^{\#} \mathrm{p}<0.05 ;{ }^{\#} \mathrm{p}<0.01$ vs. baseline; * $\mathrm{p}<0.05 ; * * \mathrm{p}<0.01$ vs. control.

${ }^{a}$ Decreased rate of latency $(\%)=($ latency of 13 th day-latency of baseline $) \times 100 \% /$ latency of baseline.

${ }^{\mathrm{b}}$ Increased rate of latency $(\%)=($ latency of after administration-latency of before administration $) \times 100 \%$ / latency of before administration.

${ }^{\mathrm{c}}$ Each group was measured after first administration on the 14th day and the last administration on the 17th day, which was the result of single administration and repeated administration, respectively.

\subsection{Mechanism of Action}

Due to its potent analgesic activity and minimal toxicity, compound $\mathbf{1 8}$ was selected for further investigation of its possible mechanism of action. The mechanism of pain transmission is complex because many different neuromodulators and receptors could be involved. Results indicated that compound 18 did not act on the opioid, $5 \mathrm{HT}_{2 \mathrm{~A}}$ and $5 \mathrm{HTU}$ receptors. It was interesting to note that compound 18 had a high affinity for $5 \mathrm{HT}_{1 \mathrm{~A}}$ (Table 7 ). The $5-\mathrm{HT}_{1 \mathrm{~A}}$ receptor functions as a somatodendritic autoreceptor that controls the release of serotonin in terminal areas. By preventing this inhibitory control of serotonin release, it is possible to enhance the analgesic effect of drugs that increase serotonin levels by facilitating both descending and ascending pathways involved in pain modulation [33]. As 5- $\mathrm{HT}_{1 \mathrm{~A}}$ receptor agonist, 8-OH-DPAT could induce hyperalgesia in rats [34]. [(3-chloro-4-fluorophenyl)-[4-fluoro-4-\{[(5-methylpyridin-2-ylmethyl)amino]methyl $\}$ piperidin-1-yl]methadone] (F13640) was a high-efficacy 5 - $\mathrm{HT}_{1 \mathrm{~A}}$ receptor agonist that exhibited an analgesic action in animal models of chronic, nociceptive and neuropathic pains [35-37]. In additional, a large number of arylpiperazines have potent affinity for 5- $\mathrm{HT}_{1 \mathrm{~A}}$ receptors [38-40]. Thus, it appears that analgesia effect of compound 18 originates from its acting on $5 \mathrm{HT}_{1 \mathrm{~A}}$ receptor.

\subsection{Structure-Activity Relationships (SAR)}

The following structure-activity relationships (SAR) could be drawn from the acetic acid induced writhing test and hot plate tests. The phenyl ring substituted with methoxy in the ortho-position (compound 10) led to more activity than the para- and meta-positions (compounds 11,12). This indicated that antinociceptive activity depended on the location of the substituent on the phenyl ring. Substitution with alkyl groups on the phenyl ring resulted in better analgesic activity, for example, 
3- $\mathrm{CF}_{3}-\mathrm{Ph}$ (compound 18) and 2,3-di- $\mathrm{CH}_{3}-\mathrm{Ph}$ (compound 19) were observed to be the most active, with $78.7 \%$ and $75.2 \%$ inhibition. However, substitution with halogen groups was found to cause a dramatic decrease of activity, as demonstrated by compounds 13-17. In the same subseries, replacement of the phenyl with aromatic heterocycle groups (compounds 20-25) resulted in a complete loss of activity. A possible reason could be that the heterocycle groups impeded the phenyl ring from making a key hydrogen bond to a tightly bound water molecule. It seemed that phenyl ring was especially important for the analgesic activity. Finally, replacing carbonyl with a $\mathrm{C}=\mathrm{N}-\mathrm{OR}$ group (compounds 26-28) resulted in the loss of activity, which indicated that the carbonyl was the key active site.

Table 7. Inhibition of the compounds for the relatively receptor.

\begin{tabular}{cccccccc}
\hline \multirow{2}{*}{ Compound } & \multirow{2}{*}{ Concentration $(\mathbf{m o l} / \mathbf{L})$} & \multicolumn{6}{c}{$\mathbf{E}_{\mathbf{m a x 1 0} \mathbf{\mu M}}{ }^{\mathbf{a}} \mathbf{( \% )}$} \\
\cline { 3 - 8 } & & $\boldsymbol{\mu}$ & $\boldsymbol{\delta}$ & $\boldsymbol{\kappa}$ & $\mathbf{5 - H T}_{\mathbf{2}}$ & $\mathbf{5 - H T}_{\mathbf{1 A}}$ & $\mathbf{5 - H T}$ uptake \\
\hline Naloxone & $10^{-5}$ & 100 & 100 & 100 & - & - & - \\
Aripiprazole & $10^{-5}$ & - & - & - & 100 & - & - \\
$5-H T$ & $10^{-5}$ & - & - & - & - & 100 & - \\
Duloxetine & $10^{-5}$ & - & - & - & - & - & 90.6 \\
w-conotoxinGVIA & $10^{-5}$ & - & - & - & - & - & - \\
18 & $10^{-5}$ & 18.1 & 0 & 2.9 & 57.7 & 96.9 & 59.3 \\
\hline
\end{tabular}

${ }^{a}$ Maximal inhibition effect at the highest tested concentration $\left(\mathrm{E}_{\max 10 \mu \mathrm{M}}\right)$.

\section{Experimental}

\subsection{General}

All the chemicals and solvents were purchased from commercial sources. Melting points were determined with a capillary melting point apparatus and are uncorrected. ${ }^{1} \mathrm{H}-\mathrm{NMR}$ spectra were recorded with an Avance 400 instrument (Bruker Biospin, version 002 with SGU). Chemical shifts are reported in ppm, using the solvent as internal standard. Coupling constants ( $J$ values) are given in Hertz (Hz). The mass spectra (MS) were recorded on an AMD-604 Mass Spectrometer operating at $70 \mathrm{eV}$.

\subsubsection{General Procedure for the Synthesis of Compounds 10-25 [20]}

To a suspension of 2-chloro-1-phenylethanone $(0.32 \mathrm{mmol})$, arylpiperazine $(0.32 \mathrm{mmol})$ and anhydrous $\mathrm{Na}_{2} \mathrm{CO}_{3}(1.22 \mathrm{mmol})$ in anhydrous $\mathrm{EtOH}(5.0 \mathrm{~mL})$ were added, and the resulting mixture was refluxed for $4 \mathrm{~h}$. There after the mixture was filtered and the filtrate was evaporated to dryness under reduced pressure. The residues were recrystallized from isopropanol to give compounds 10-25.

2-(4-(2-Methoxyphenyl)piperazin-1-yl)-1-phenylethanone (10): Yield 84.7\%; Mp 102-104 ${ }^{\circ} \mathrm{C} ;{ }^{1} \mathrm{H}-\mathrm{NMR}$ $\left(\mathrm{D}_{2} \mathrm{O}\right) \delta: 7.96(\mathrm{~d}, 2 \mathrm{H}, J=7.2 \mathrm{~Hz}, \mathrm{Ar}-\mathrm{H}), 7.72(\mathrm{t}, 1 \mathrm{H}, J=7.2 \mathrm{~Hz}, \mathrm{Ar}-\mathrm{H}), 7.55(\mathrm{t}, 2 \mathrm{H}, J=7.6 \mathrm{~Hz}, \mathrm{Ar}-\mathrm{H})$, 7.16 (t, 1H, $J=7.6 \mathrm{~Hz}, \mathrm{Ar}-\mathrm{H}), 7.12(\mathrm{~d}, 1 \mathrm{H}, J=7.6 \mathrm{~Hz}, \mathrm{Ar}-\mathrm{H}), 7.05(\mathrm{~d}, 1 \mathrm{H}, J=7.6 \mathrm{~Hz}, \mathrm{Ar}-\mathrm{H}), 7.01$ (t, 1H, $J=7.6 \mathrm{~Hz}, \mathrm{Ar}-\mathrm{H}$ ), 5.00 (s, 2H, N-CH$-\mathrm{CO}), 3.82$ (s, 3H, $-\mathrm{OCH}_{3}$ ), 3.58 (br, 4H, piperazine-H), 3.39 (br, $4 \mathrm{H}$, piperazine-H); MS (m/z) $311.3\left([\mathrm{M}+\mathrm{H}]^{+}\right)$. 
2-(4-(3-Methoxyphenyl)piperazin-1-yl)-1-phenylethanone (11): Yield 84.7\%; Mp 96-97 ${ }^{\circ} \mathrm{C}$; ${ }^{1} \mathrm{H}-\mathrm{NMR}$ $\left(\mathrm{CDCl}_{3}\right) \delta: 8.01(\mathrm{~d}, 2 \mathrm{H}, J=7.6 \mathrm{~Hz}, \mathrm{Ar}-\mathrm{H}), 7.64(\mathrm{t}, 1 \mathrm{H}, J=7.6 \mathrm{~Hz}, \mathrm{Ar}-\mathrm{H}), 7.53(\mathrm{t}, 2 \mathrm{H}, J=7.6 \mathrm{~Hz}, \mathrm{Ar}-\mathrm{H})$, $7.10(\mathrm{t}, 1 \mathrm{H}, J=8.0 \mathrm{~Hz}, \mathrm{Ar}-\mathrm{H}), 6.52(\mathrm{dd}, 1 \mathrm{H}, J=7.6$ and $2.0 \mathrm{~Hz}, \mathrm{Ar}-\mathrm{H}), 6.44$ (t,1H, Ar-H), 6.36 (dd, $1 \mathrm{H}$, Ar-H), $3.88\left(\mathrm{~s}, 2 \mathrm{H}, \mathrm{N}-\mathrm{CH}_{2}-\mathrm{CO}\right), 3.71\left(\mathrm{~s}, 3 \mathrm{H},-\mathrm{OCH}_{3}\right), 3.13(\mathrm{t}, 4 \mathrm{H}$, piperazine-H), $2.65(\mathrm{t}, 4 \mathrm{H}$, piperazine-H); MS (ESI) m/z $311.3\left([\mathrm{M}+\mathrm{H}]^{+}\right)$.

2-(4-(4-Methoxyphenyl)piperazin-1-yl)-1-phenylethanone (12): Yield 85\%; Mp 107-109 ${ }^{\circ} \mathrm{C}$; ${ }^{1} \mathrm{H}-\mathrm{NMR}$ $\left(\mathrm{CDCl}_{3}\right) \delta: 7.94(\mathrm{~d}, 2 \mathrm{H}, J=7.6 \mathrm{~Hz}, \mathrm{Ar}-\mathrm{H}), 7.72(\mathrm{t}, 1 \mathrm{H}, J=7.6 \mathrm{~Hz}, \mathrm{Ar}-\mathrm{H}), 7.55(\mathrm{t}, 2 \mathrm{H}, J=7.6 \mathrm{~Hz}, \mathrm{Ar}-\mathrm{H})$, $7.12(\mathrm{~d}, 2 \mathrm{H}, J=8.8 \mathrm{~Hz}, \mathrm{Ar}-\mathrm{H}), 7.08$ (d, 2H, $J=8.8 \mathrm{~Hz}, \mathrm{Ar}-\mathrm{H}), 5.00$ (s, 2H, N-CH $-\mathrm{CO}), 3.76$ (s, 3H, $\left.-\mathrm{OCH}_{3}\right), 3.60$ (br, 4H, piperazine-H), 3.50 (br, 4H, piperazine-H); MS (ESI) m/z $311.3\left([\mathrm{M}+\mathrm{H}]^{+}\right)$.

2-(4-(2-Chlorophenyl)piperazin-1-yl)-1-phenylethanone (13): Yield 93\%; Mp 89-90 ${ }^{\circ} \mathrm{C} ;{ }^{1} \mathrm{H}-\mathrm{NMR}\left(\mathrm{CDCl}_{3}\right) \delta$ : 8.02 (d, 2H, $J=7.6 \mathrm{~Hz}, \mathrm{Ar}-\mathrm{H}), 7.64$ (t, $1 \mathrm{H}, J=7.6 \mathrm{~Hz}, \mathrm{Ar}-\mathrm{H}), 7.53$ (t, 2H, $J=7.6 \mathrm{~Hz}, \mathrm{Ar}-\mathrm{H}), 7.39$ (dd, $1 \mathrm{H}, J=7.6$ and $1.2 \mathrm{~Hz}, \mathrm{Ar}-\mathrm{H}), 7.28(\mathrm{td}, 1 \mathrm{H}, J=7.6$ and $1.2 \mathrm{~Hz}, \mathrm{Ar}-\mathrm{H}), 7.16(\mathrm{dd}, 1 \mathrm{H}, J=7.6$ and 1.2 $\mathrm{Hz}, \mathrm{Ar}-\mathrm{H}), 7.03$ (td, $1 \mathrm{H}, J=7.6$ and $1.2 \mathrm{~Hz}, \mathrm{Ar}-\mathrm{H}), 3.93$ (s, 2H, N-CH2-CO), 2.99 (br, 4H, piperazine-H), 2.71 (br, 4H, piperazine-H); MS (ESI) m/z $315.1\left([\mathrm{M}+\mathrm{H}]^{+}\right)$.

2-(4-(3-Chlorophenyl)piperazin-1-yl)-1-phenylethanone (14): Yield 87\%; Mp 115-116 ${ }^{\circ} \mathrm{C}$; ${ }^{1} \mathrm{H}-\mathrm{NMR}$ $\left(\mathrm{CDCl}_{3}\right) \delta: 8.01(\mathrm{~d}, 2 \mathrm{H}, J=7.6 \mathrm{~Hz}, \mathrm{Ar}-\mathrm{H}), 7.64(\mathrm{t}, 1 \mathrm{H}, J=7.2 \mathrm{~Hz}, \mathrm{Ar}-\mathrm{H}), 7.53(\mathrm{t}, 2 \mathrm{H}, J=8.0 \mathrm{~Hz}, \mathrm{Ar}-\mathrm{H})$, 7.20 (t, $1 \mathrm{H}, J=8.0 \mathrm{~Hz}, \mathrm{Ar}-\mathrm{H}), 6.93$ (t, $1 \mathrm{H}, J=2.0 \mathrm{~Hz}, \mathrm{Ar}-\mathrm{H}), 6.89$ (dd, $1 \mathrm{H}, J=7.6$ and $1.2 \mathrm{~Hz}, \mathrm{Ar}-\mathrm{H}$ ), 6.77(dd, $1 \mathrm{H}, J=7.6$ and $1.2 \mathrm{~Hz}, \mathrm{Ar}-\mathrm{H}), 3.92\left(\mathrm{~s}, 2 \mathrm{H}, \mathrm{N}-\mathrm{CH}_{2}-\mathrm{CO}\right), 3.18(\mathrm{t}, 4 \mathrm{H}, J=0.8 \mathrm{~Hz}$, piperazine-H), $2.66\left(\mathrm{t}, 4 \mathrm{H}, J=0.8 \mathrm{~Hz}\right.$, piperazine-H); MS (ESI) m/z $315.1\left([\mathrm{M}+\mathrm{H}]^{+}\right)$.

2-(4-(4-Chlorophenyl)piperazin-1-yl)-1-phenylethanone (15): Yield 90\%; Mp 137-138 ${ }^{\circ} \mathrm{C} ;{ }^{1} \mathrm{H}-\mathrm{NMR}\left(\mathrm{CDCl}_{3}\right)$ $\delta: 8.01$ (d, 2H, $J=7.6 \mathrm{~Hz}, \mathrm{Ar}-\mathrm{H}), 7.64$ (t, 1H, $J=7.2 \mathrm{~Hz}, \mathrm{Ar}-\mathrm{H}), 7.53(\mathrm{t}, 2 \mathrm{H}, J=7.6 \mathrm{~Hz}, \mathrm{Ar}-\mathrm{H}), 7.22$ (t, 2H, $J=8.8 \mathrm{~Hz}, \mathrm{Ar}-\mathrm{H}), 6.94$ (d, 2H, $J=8.8 \mathrm{~Hz}, \mathrm{Ar}-\mathrm{H}), 3.92$ (s, 2H, N-CH $2-\mathrm{CO}), 3.14$ (t, 4H, $J=0.8 \mathrm{~Hz}$, piperazine-H), $2.66\left(\mathrm{t}, 4 \mathrm{H}, J=0.8 \mathrm{~Hz}\right.$, piperazine-H); MS (ESI) $\mathrm{m} / \mathrm{z} 315.1\left([\mathrm{M}+\mathrm{H}]^{+}\right)$.

2-(4-(2,3-Dichlorophenyl)piperazin-1-yl)-1-phenylethanone (16): Yield 94\%; Mp 106-107 ${ }^{\circ} \mathrm{C}$; ${ }^{1} \mathrm{H}-\mathrm{NMR}\left(\mathrm{CDCl}_{3}\right) \delta: 8.01(\mathrm{~d}, 2 \mathrm{H}, J=7.6 \mathrm{~Hz}, \mathrm{Ar}-\mathrm{H}), 7.59(\mathrm{tt}, 1 \mathrm{H}, J=7.6$ and $1.2 \mathrm{~Hz}, \mathrm{Ar}-\mathrm{H}), 7.47(\mathrm{t}, 2 \mathrm{H}$, $J=7.6 \mathrm{~Hz}, \mathrm{Ar}-\mathrm{H}), 7.17-7.13(\mathrm{~m}, 2 \mathrm{H}, \mathrm{Ar}-\mathrm{H}), 6.97(\mathrm{dd}, 1 \mathrm{H}, J=5.6$ and $2.8 \mathrm{~Hz}, \mathrm{Ar}-\mathrm{H}), 3.94(\mathrm{~s}, 2 \mathrm{H}$, $\left.\mathrm{N}-\mathrm{CH}_{2}-\mathrm{CO}\right) 3.16$ (t, 4H, $J=4.8 \mathrm{~Hz}$, piperazine-H), 2.85 (br, 4H, piperazine-H); MS (ESI) m/z 349.3 $\left([\mathrm{M}+\mathrm{H}]^{+}\right)$.

2-(4-(4-Fluorophenyl)piperazin-1-yl)-1-phenylethanone (17): Yield 91\%; Mp 127-128 ${ }^{\circ} \mathrm{C}$; ${ }^{1} \mathrm{H}-\mathrm{NMR}$ $\left(\mathrm{CDCl}_{3}\right) \delta ; 8.01(\mathrm{~d}, 2 \mathrm{H}, J=7.2 \mathrm{~Hz}, \mathrm{Ar}-\mathrm{H}), 7.64$ (t, 1H, J=7.2 Hz, Ar-H), 7.53 (t, 2H, J=7.6 Hz, Ar-H), 7.04 (t, 2H, $J=8.8 \mathrm{~Hz}, \mathrm{Ar}-\mathrm{H}), 6.95-6.93$ (m, 2H, Ar-H), 3.92 (s, 2H, N-CH $-\mathrm{CO}), 3.08$ (t, 4H, J= 5.2 Hz, piperazine-H), 2.67 (t, 4H, $J=5.2 \mathrm{~Hz}$, piperazine-H); MS (ESI) $\mathrm{m} / \mathrm{z} 299.1\left([\mathrm{M}+\mathrm{H}]^{+}\right)$.

2-(4-(3-(Trifluoromethyl)phenyl)piperazin-1-yl)-1-phenylethanone (18): Yield 91.3\%; Mp 122-124 ${ }^{\circ} \mathrm{C}$; ${ }^{1} \mathrm{H}-\mathrm{NMR}$ (MeOD) $\delta: 7.90$ (d, 2H, $\left.J=7.6 \mathrm{~Hz}, \mathrm{Ar}-\mathrm{H}\right), 7.58$ (t, 1H, J=7.6 Hz, Ar-H), 7.43(t, 2H, J= 7.6 Hz, Ar-H), 7.32 (t, 1H, J=8.0 Hz, Ar-H), 7.14 (br, 2H, Ar-H), 7.04 (d, 1H, J=8.0 Hz, Ar-H), 4.93 (s, 2H, $\mathrm{N}-\mathrm{CH}_{2}-\mathrm{CO}$ ), 3.79-3.14 (br, $8 \mathrm{H}$, piperazine-H); MS (ESI) m/z $349.3\left([\mathrm{M}+\mathrm{H}]^{+}\right)$. 
2-(4-(2,3-Dimethylphenyl)piperazin-1-yl)-1-phenylethanone (19): Yield 92.5\%; Mp 98-99 ${ }^{\circ} \mathrm{C}$; ${ }^{1} \mathrm{H}-\mathrm{NMR}$ (MeOD) $\delta: 7.92$ (d, 2H, $J=7.6 \mathrm{~Hz}, \mathrm{Ar}-\mathrm{H}), 7.59$ (t, 1H, $J=7.6 \mathrm{~Hz}, \mathrm{Ar}-\mathrm{H}), 7.45(\mathrm{t}, 2 \mathrm{H}, J=7.6 \mathrm{~Hz}, \mathrm{Ar}-\mathrm{H})$, 6.94 (t, $1 \mathrm{H}, J=7.6 \mathrm{~Hz}, \mathrm{Ar}-\mathrm{H}), 6.86$ (d, 1H, J=7.6 Hz, Ar-H), 6.82 (d, 1H, J=7.6 Hz, Ar-H), 4.94 (s, 2H, N-CH $2-\mathrm{CO}$ ), 3.59-3.09 (br, 8H, piperazine-H), 2.12 (s, 6H, Ar- $\mathrm{CH}_{3}$ ); MS (ESI) m/z 309.3 ([M + H] $]^{+}$).

2-(4-(6-Methoxybenzo[d]thiazol-2-yl)piperazin-1-yl)-1-phenylethanone (20): Yield 85\%; Mp 159-161 ${ }^{\circ} \mathrm{C}$; ${ }^{1} \mathrm{H}-\mathrm{NMR}\left(\mathrm{CDCl}_{3}\right) \delta: 7.92(\mathrm{~d}, 2 \mathrm{H}, J=7.6 \mathrm{~Hz}, \mathrm{Ar}-\mathrm{H}), 7.58(\mathrm{tt}, 1 \mathrm{H}, J=7.2$ and $1.2 \mathrm{~Hz}, \mathrm{Ar}-\mathrm{H}), 7.47(\mathrm{t}, 2 \mathrm{H}$, $J=7.6 \mathrm{~Hz}, \mathrm{Ar}-\mathrm{H}), 7.45$ (s, 1H, Ar-H), $7.15(\mathrm{~d}, 1 \mathrm{H}, J=2.4 \mathrm{~Hz}, \mathrm{Ar}-\mathrm{H}), 6.90$ (dd, $1 \mathrm{H}, J=7.6$ and $2.4 \mathrm{~Hz}$, $\mathrm{Ar}-\mathrm{H}), 3.90$ (s, 2H, N-CH $-\mathrm{CO}), 3.82\left(\mathrm{~s}, 3 \mathrm{H},-\mathrm{OCH}_{3}\right), 3.68(\mathrm{t}, 4 \mathrm{H}, J=5.2 \mathrm{~Hz}$, piperazine- $\mathrm{H}), 2.76(\mathrm{t}, 4 \mathrm{H}$, $J=5.2 \mathrm{~Hz}$, piperazine-H); MS (ESI) $\mathrm{m} / \mathrm{z} 368.3\left([\mathrm{M}+\mathrm{H}]^{+}\right)$.

2-(4-(6-methylbenzo[d]thiazol-2-yl)piperazin-1-yl)-1-phenylethanone $\quad$ (21): $\quad$ Yield $\quad 80 \% ; \quad \mathrm{Mp}$ 155.5-157.0 ${ }^{\circ} \mathrm{C} ;{ }^{1} \mathrm{H}-\mathrm{NMR}\left(\mathrm{CDCl}_{3}\right) \delta: 8.00(\mathrm{~d}, 2 \mathrm{H}, J=7.6 \mathrm{~Hz}, \mathrm{Ar}-\mathrm{H}), 7.64(\mathrm{t}, 1 \mathrm{H}, J=7.6 \mathrm{~Hz}, \mathrm{Ar}-\mathrm{H})$, 7.56-7.51 (m, 3H, Ar-H), 7.34 (d, 1H, $J=8.4 \mathrm{~Hz}, \mathrm{Ar}-\mathrm{H}), 7.08$ (dd, 1H, $J=7.6$ and $0.8 \mathrm{~Hz}, \mathrm{Ar}-\mathrm{H}), 3.97$ (s, $\left.2 \mathrm{H}, \mathrm{N}-\mathrm{CH}_{2}-\mathrm{CO}\right), 3.55(\mathrm{t}, 4 \mathrm{H}, J=1.2 \mathrm{~Hz}$, piperazine- $\mathrm{H}), 2.68(\mathrm{t}, 4 \mathrm{H}, J=1.2 \mathrm{~Hz}$, piperazine-H), 2.33 (s, 3H, Ar- $\left.\mathrm{CH}_{3}\right)$; MS (ESI) m/z $352.3\left([\mathrm{M}+\mathrm{H}]^{+}\right)$.

2-(4-(4-Methylbenzo[d]thiazol-2-yl)piperazin-1-yl)-1-phenylethanone $\quad$ (22): $\quad$ Yield $\quad 82 \% ; \quad \mathrm{Mp}$ 139-141 ${ }^{\circ} \mathrm{C} ;{ }^{1} \mathrm{H}-\mathrm{NMR}\left(\mathrm{CDCl}_{3}\right) \delta: 8.00(\mathrm{~m}, 2 \mathrm{H}, \mathrm{Ar}-\mathrm{H}), 7.58(\mathrm{tt}, 1 \mathrm{H}, J=7.2$ and $1.2 \mathrm{~Hz}, \mathrm{Ar}-\mathrm{H})$, 7.49-7.43 (m, 3H, Ar-H), $7.12(\mathrm{~d}, 1 \mathrm{H}, J=7.2 \mathrm{~Hz}, \mathrm{Ar}-\mathrm{H}), 6.98$ (t, 1H, J=7.6 Hz, Ar-H), 3.91 (s, 2H, $\left.\mathrm{N}-\mathrm{CH}_{2}-\mathrm{CO}\right), 3.74(\mathrm{t}, 4 \mathrm{H}, J=5.2 \mathrm{~Hz}$, piperazine-H), $2.77(\mathrm{t}, 4 \mathrm{H}, J=5.2 \mathrm{~Hz}$, piperazine- $\mathrm{H}), 2.56(\mathrm{~s}, 3 \mathrm{H})$; MS (ESI) m/z $352.3\left([\mathrm{M}+\mathrm{H}]^{+}\right)$.

2-(4-(6-Chlorobenzo[d]thiazol-2-yl)piperazin-1-yl)-1-phenylethanone $\quad$ (23): $\quad$ Yield $\quad 81 \% ; \quad \mathrm{Mp}$ 172-173.5 ${ }^{\circ} \mathrm{C} ;{ }^{1} \mathrm{H}-\mathrm{NMR}\left(\mathrm{CDCl}_{3}\right)$ 8: $7.98(\mathrm{~d}, 2 \mathrm{H}, J=7.6 \mathrm{~Hz}, \mathrm{Ar}-\mathrm{H}), 7.60$ (tt, $1 \mathrm{H}, J=7.2$ and $1.2 \mathrm{~Hz}$, Ar-H), 7.57 (d, 1H, $J=2.0 \mathrm{~Hz}, \mathrm{Ar}-\mathrm{H}), 7.48$ (t, 2H, $J=7.6 \mathrm{~Hz}, \mathrm{Ar}-\mathrm{H}), 7.45$ (d, 1H, $J=8.8 \mathrm{~Hz}, \mathrm{Ar}-\mathrm{H})$, $7.25(\mathrm{dd}, 1 \mathrm{H}, J=8.8$ and $2.0 \mathrm{~Hz}, \mathrm{Ar}-\mathrm{H}), 3.97\left(\mathrm{~s}, 2 \mathrm{H}, \mathrm{N}-\mathrm{CH}_{2}-\mathrm{CO}\right), 3.76(\mathrm{t}, 4 \mathrm{H}, J=5.2 \mathrm{~Hz}$, piperazine-H), 2.85 (br, 4H, piperazine-H); MS (ESI) m/z $372.3\left([\mathrm{M}+\mathrm{H}]^{+}\right)$.

2-(4-(4-Chlorobenzo[d]thiazol-2-yl)piperazin-1-yl)-1-phenylethanone $\quad$ (24): $\quad$ Yield $\quad 81 \% ; \quad \mathrm{Mp}$ 146-148 ${ }^{\circ} \mathrm{C}$; ${ }^{1} \mathrm{H}-\mathrm{NMR}\left(400 \mathrm{MHz}, \mathrm{CDCl}_{3}\right) \delta: 7.98$ (d, 2H, $\left.J=7.6 \mathrm{~Hz}, \mathrm{Ar}-\mathrm{H}\right), 7.59$ (t, $1 \mathrm{H}, J=7.6 \mathrm{~Hz}$, Ar-H), 7.49-7.42 (br, 3H, Ar-H), 7.31 (dd, 1H, J=7.6 and 1.2Hz, Ar-H), 6.98 (t, 1H, J=8.0 Hz, Ar-H), $3.77\left(\mathrm{~s}, 2 \mathrm{H}, \mathrm{N}-\mathrm{CH}_{2}-\mathrm{CO}\right), 3.72(\mathrm{t}, 4 \mathrm{H}, J=5.2 \mathrm{~Hz}$, piperazine-H), 2.77 (t, $4 \mathrm{H}, J=5.2 \mathrm{~Hz}$, piperazine-H); MS (ESI) m/z $372.3\left([\mathrm{M}+\mathrm{H}]^{+}\right)$.

2-(4-(Pyrimidin-2-yl)piperazin-1-yl)-1-phenyl ethanone (25): Yield 90\%; Mp 156-158 ${ }^{\circ} \mathrm{C}$; ${ }^{1} \mathrm{H}-\mathrm{NMR}$ $\left(\mathrm{D}_{2} \mathrm{O}\right) \delta: 8.51(\mathrm{~d}, 2 \mathrm{H}, J=5.2 \mathrm{~Hz}, \mathrm{Ar}-\mathrm{H}), 7.91$ (d, 2H, $\left.J=7.6 \mathrm{~Hz}, \mathrm{Ar}-\mathrm{H}\right), 7.68$ (t, 1H, $\left.J=7.6 \mathrm{~Hz}, \operatorname{Ar}-\mathrm{H}\right)$, 7.51 (t, 2H, $J=8.0 \mathrm{~Hz}, \mathrm{Ar}-\mathrm{H}), 6.97$ (t, 1H, $J=5.2 \mathrm{~Hz}, \mathrm{Ar}-\mathrm{H}), 5.00$ (s, 2H, N-CH$-\mathrm{CO}$ ), 4.14-2.89 (br, $8 \mathrm{H}$, piperazine-H); MS (ESI) $\mathrm{m} / \mathrm{z} 283.2\left([\mathrm{M}+\mathrm{H}]^{+}\right)$.

\subsubsection{General Procedure for the Synthesis of Compounds 26-28}

A mixture of hydroxylamine hydrochloride or N-ethylhydroxylamine hydrochloride $(0.012 \mathrm{~mol})$, compound $\mathbf{1 0}$ or $\mathbf{1 2}$ and $20 \%$ aqueous sodium hydroxide $(12 \mathrm{~mL})$ in water $(10 \mathrm{~mL})$ was heated at 
$100{ }^{\circ} \mathrm{C}$ for $1 \mathrm{~h}$. Reaction was cooled to room temperature, and then the precipitate is collected by filtration and washed with $50 \mathrm{~mL}$ water, gave the corresponding oxime 26-28.

2-(4-(4-Methoxyphenyl)piperazin-1-yl)-1-phenylethanone oxime (26): Yield 65\%; Mp 168-170 ${ }^{\circ} \mathrm{C}$; ${ }^{1} \mathrm{H}-\mathrm{NMR}\left(\mathrm{CDCl}_{3}\right) \delta: 11.45$ (s, 1H, -NOH), 7.77 (dd, 2H, $J=7.6$ and 1.2 Hz, Ar-H), 7.39-7.34 (br, 3H, $\mathrm{Ar}-\mathrm{H}), 6.84$ (d, 2H, $J=9.2 \mathrm{~Hz}, \mathrm{Ar}-\mathrm{H}), 6.76$ (d, 2H, $J=9.2 \mathrm{~Hz}, \mathrm{Ar}-\mathrm{H}), 3.68$ (s, 2H, N-CH $2-\mathrm{CO}), 3.66$ (s, 3H, $\left.-\mathrm{OCH}_{3}\right), 2.93$ (br, 4H, piperazine-H), 2.57 (br, 4H, piperazine-H); MS (ESI) m/z $326.2\left([\mathrm{M}+\mathrm{H}]^{+}\right)$.

2-(4-(2-Methoxyphenyl)piperazin-1-yl)-1-phenylethanone oxime (27): Yield 65\%; Mp 129-131 ${ }^{\circ} \mathrm{C}$; ${ }^{1} \mathrm{H}-\mathrm{NMR}\left(\mathrm{CDCl}_{3}\right)$ \%: $12.70(\mathrm{~s}, 1 \mathrm{H},-\mathrm{NOH}), 7.86-7.84$ (br, 2H, Ar-H), 7.48(t, 3H, J=3.2 Hz, Ar-H), 6.97-6.89 (m, 4H, Ar-H), $4.53\left(\mathrm{~s}, 2 \mathrm{H}, \mathrm{N}_{-} \mathrm{CH}_{2}-\mathrm{CO}\right), 3.77\left(\mathrm{~s}, 3 \mathrm{H}, \mathrm{OCH}_{3}\right), 3.45-3.05$ (br, 8H, piperazine-H); MS (ESI) m/z $326.2\left([\mathrm{M}+\mathrm{H}]^{+}\right)$.

2-(4-(2-Methoxyphenyl)piperazin-1-yl)-1-phenylethanone ethyl oxime (28): Yield 70\%; Mp 145-147 ${ }^{\circ} \mathrm{C}$; ${ }^{1} \mathrm{H}-\mathrm{NMR}\left(\mathrm{CDCl}_{3}\right) \delta: 7.84(\mathrm{dd}, 2 \mathrm{H}, J=6.8$ and $2.0 \mathrm{~Hz}, \mathrm{Ar}-\mathrm{H}), 7.50-7.46$ (br, 3H, Ar-H), 7.04-6.87 (m, 4H, Ar-H), 4.54 (s, 2H, N-CH $-\mathrm{CO}), 4.34\left(\mathrm{q}, 2 \mathrm{H}, J=7.2 \mathrm{~Hz}, \mathrm{~N}-\mathrm{OCH}_{2} \mathrm{CH}_{3}\right), 3.78(\mathrm{~s}, 3 \mathrm{H}$, $\mathrm{OCH}_{3}$ ), 3.45-3.09 (br, 8H, piperazine-H), 1.34 (t, 3H, N-OCH $\left.\mathrm{CH}_{3}\right)$; MS (ESI) m/z $354.2\left([\mathrm{M}+\mathrm{H}]^{+}\right.$).

\subsection{Pharmacology}

\subsubsection{Animals}

Chinese Kun Ming (KM) Mice (20 $\pm 2.0 \mathrm{~g}$ ) and Sprague-Dawley (SD) rats (250 $\pm 5.0 \mathrm{~g}$ ) were used as experimental animals in this study. Animals were housed under standardized conditions for light and temperature and received standard rat chow and tap water ad libitum. Animals were randomly assigned to different experimental groups, each kept in a separate cage.

\subsubsection{Acetic Acid-Induced Abdominal Constrictions Assay [21]}

Mice were divided into groups of ten each, to test the abdominal constriction response caused by intraperitoneal injection of diluted acetic acid $(0.6 \%, 0.4 \mathrm{~mL})$. Compounds were administered orally $(10,20,40 \mathrm{mg} / \mathrm{kg})$ as a suspension in $5 \%$ saline (vehicle). Acetylsalicylic acid $(100 \mathrm{mg} / \mathrm{kg}$, po) was used as standard drug under same conditions. Control animals received an equal volume of vehicle. Test group mice received acetic acid $1 \mathrm{~h}$ after drug treatment. The number of constrictions per animal was recorded for 15 minutes. For scoring purposes, a writhe was indicated by stretching of the abdomen with simultaneous stretching of at least one hind limb. Analgesic activity was expressed as percentage of inhibition of constrictions in comparison to control group:

Inhibition of constrictions $(\%)=($ constrictions of control group - constrictions of test compounds group) $\times 100 \% /$ constrictions of control group

\subsubsection{Hot Plate Test [22]}

The mice were treated with saline solution, morphine $(5 \mathrm{mg} / \mathrm{kg}, \mathrm{sc})$ or test compounds $(10,20,40 \mathrm{mg} / \mathrm{kg}$, po), and placed individually on a hot-plate maintained at $55 \pm 1{ }^{\circ} \mathrm{C}$. The time between placing the 
animal on the hot-plate and the occurrence of either the licking of the hind paws, shaking the paw or jumping off the surface was recorded as response latency. Mice with baseline latencies of $<5$ or $>30 \mathrm{~s}$ were eliminated from the study, and the cut-off time for the hot-plate latencies was set at $60 \mathrm{~s}$. The animals were treated $60 \mathrm{~min}$ before the assay:

Increased rate of latency $(\%)=($ latency of after administration - latency of before administration $) \times$ $100 \%$ / latency of before administration

\subsubsection{Acute Toxicity Study $\left(\mathrm{LD}_{50}\right)[23]$}

The test compounds were investigated for their acute toxicity $\left(\mathrm{LD}_{50}\right)$ in mice. The test compounds were given orally at different dose levels in separate groups of animals. After $24 \mathrm{~h}$ of drug administration, percent mortality in each group was observed. The $\mathrm{LD}_{50}$ calculations were done by the Bliss method.

\subsubsection{Exploratory Locomotor Activity [24]}

Exploratory locomotor activity was assessed in 14 automated activity frames equipped with infrared photobeam emitters and sensors. To assess drug effect on exploratory locomotor activity, the mice were transferred to new home cages immediately before test start and activity was measured for $30 \mathrm{~min}$. Test or reference compounds were orally administered $30 \mathrm{~min}$ before test start at the following doses: 18 and $19,40,80,160 \mathrm{mg} / \mathrm{kg}$; clonazepam: $15.0 \mathrm{mg} / \mathrm{kg}$. The average speed was measured before and 30 , 60, 90 and $120 \mathrm{~min}$ after treatment.

\subsubsection{Formalin Test [28]}

Male rats, 10/group, were treated with the tested compounds $(40,80,160 \mathrm{mg} / \mathrm{kg}$, po) and morphine $(5 \mathrm{mg} / \mathrm{kg}$, ip), and $1 \mathrm{~h}$ later, a $5 \%$ formalin solution $(50 \mu \mathrm{L})$ was injected subcutaneously into the dorsal surface of their right hind paws. The formalin induced a typical licking or biting of the injected paw (flinching behavior). The animals were placed in a transparent chamber, The total time (s) spent licking the injected paw during periods of 0-5 $\mathrm{min}$ and 15-60 $\mathrm{min}$ after formalin injection was measured as an indicator of nociceptive behavior.

\subsection{Spared Nerve Injury (SNI) Neuropathy Assay}

\subsubsection{Group and Design}

Rats were randomly divided into several groups (10/group): sham, control, gabapentin (40 mg/kg) and compounds group (40, 80 and $160 \mathrm{mg} / \mathrm{kg}$ ). Pain threshold base value of each group were measured 1-2 days before operation with the values of two days were picked. The pain threshold values were measured again 13 days after the operation to check if the model were successful. Gabapentin, 18 and 19 were dosed orally twice a day for four days (14th, 15th, 16th and 17th day). The behavior test was performed $1 \mathrm{~h}$ after administration. Each group was measured after the first administration on the 14th day and the last administration on the 17th day, which was the result of single administration and repeated administration, respectively. 


\subsubsection{Surgery $[31,41]$}

Rats were anaesthetized with $10 \%$ chloral hydrate and the skin of the lateral left thigh was incised. The cranial and caudal parts of the biceps femoris muscle were separated and held apart by a retractor to expose the sciatic nerve and its three terminal branches: the sural, common peroneal and tibial nerves. The common peroneal and the tibial nerves were tight-ligated with 5.0 silk and sectioned distal to the ligation, removing 2-4 mm of the distal nerve stump. Any stretching or contact with the intact sural nerve was avoided. The muscle and skin were closed in two layers and the skin sutured together with hidden stitches to avoid any opening of the wound by biting. Sham controls involved exposure of the sciatic nerve and its branches without any lesion.

\subsubsection{Mechanical Withdrawal Threshold [41]}

Rats were placed in a transparent plexiglass box $(22 \mathrm{~cm} \times 12 \mathrm{~cm} \times 22 \mathrm{~cm})$, with a metal mesh floor to allow for stimulation of the lateral plantar surface of the paw (innervated by the spared sural nerve). The animals were adapted to the testing situation for at least $30 \mathrm{~min}$ before the session started. A set of von Frey monofilaments was used to test the mechanical withdrawal threshold of the hindpaws. The monofilaments were applied in increasing force until the rat withdrew the paw. For each measurement, the paw was sampled four times and a mean calculated.

\subsection{Chronic Constriction Injury (CCI) Neuropathy Assay}

\subsubsection{Group and Design}

Rats were randomly divided into several groups (10/group): sham, control, gabapentin (40 mg/kg) and compounds group (40, 80 and $160 \mathrm{mg} / \mathrm{kg}$ ). Pain threshold base value of each group were measured 1-2 days before operation with the values of two days were picked. The Pain threshold values were measured again 13 days after the operation to check if the model were successful. Gabapentin, 18 and 19 were dosed orally twice a day for four days (14th, 15th, 16th and 17th day). The behavior test after $1 \mathrm{~h}$ of administration. Each group was measured after first administration on the 14th day and the last administration on the 17th day, which was the result of single administration and repeated administration, respectively.

\subsubsection{Surgey [32]}

Rats were anaesthetized with chloral hydrate. The common sciatic nerve is exposed at the level of the mid thigh by blunt dissection through the biceps femoris. A section of nerve proximal to the sciatic trifucation, about the nerve was freed of adhering tissue and four ligatures (4/0 silk tread) were tied loosely around it with about $1 \mathrm{~mm}$ spacing. The length of the nerve thus affected was $1 \mathrm{~cm}$ long. The incision is closed in layers and the animals are allowed to recover. Surgery for the sham condition involved exposing the sciatic nerve, but the nerve was not isolated from surrounding tissue. 


\subsubsection{Behavioral Testing}

\subsubsection{Mechanical Withdrawal Threshold (MWT) [42]}

The rats were placed in a transparent plexiglass box $(22 \mathrm{~cm} \times 12 \mathrm{~cm} \times 22 \mathrm{~cm})$, with a $5 \times 5 \mathrm{~mm}$ wire-mesh grid floor to allow for stimulation of the lateral plantar surface of the paw(innervated by the spared sural nerve). The animals were adapted to the testing situation for at least 30 min before the session started. A set of von Frey monofilaments was used to test the mechanical withdrawal threshold of the hindpaws. The monofilaments were applied in increasing force until the rat withdrew the paw. For each measurement, the paw was sampled four times and a mean calculated. At least $3 \mathrm{~min}$ elapsed between.

\subsubsection{Thermal Withdrawal Latency (TWL) [43]}

The rats were placed in a clear plastic chamber $(22 \mathrm{~cm} \times 12 \mathrm{~cm} \times 22 \mathrm{~cm})$ with a $3 \mathrm{~mm}$ glass floor and allowed to acclimate to their environment for $30 \mathrm{~min}$ before testing. A radiant heat source (BME-410A) is aimed at the mid-plantar hindpaw (sciatic nerve territory) through the glass floor. The latencies for the withdrawal reflex in both paws are recorded. A $60 \mathrm{~s}$ cut off is used to prevent permanent injury to the skin. For each measurement, the paw was sampled four times and a mean calculated. At least 3 min elapsed between tests.

\subsection{5-HT ${ }_{1 A}$ Binding Assay [44]}

Cerebral cortex was homogenized in 20 volumes of ice-cold Tris- $\mathrm{HCl}$ buffer $(50 \mathrm{mM}, \mathrm{pH} 7.7$ at $22{ }^{\circ} \mathrm{C}$ ) using ULTRA TURAX homogeniser, and was then centrifuged at 32,000 $\mathrm{g}$ for $10 \mathrm{~min}$. The supernatant fraction was discarded, and pellet was resuspended in the same volume of Tris-HCl buffer and was then centrifuged. Before the third centrifugation, the samples were incubated at $37^{\circ} \mathrm{C}$ for $10 \mathrm{~min}$. The final pellet was resuspended in Tris- $\mathrm{HCl}$ buffer containing $10 \mu \mathrm{M}$ pargyline, $4 \mathrm{mM} \mathrm{CaCl}_{2}$ and $0.1 \%$ ascorbic acid. One milliliter of the tissue suspension ( $9 \mathrm{mg}$ of wet weight), $100 \mu \mathrm{L}$ of $10 \mu \mathrm{M}$ serotonin (for unspecific binding), $100 \mu \mathrm{L}$ of $\left[{ }^{3} \mathrm{H}\right]-8-\mathrm{OH}-\mathrm{DPAT}$ and $100 \mu \mathrm{L}$ of analyzed compound were incubated at $37{ }^{\circ} \mathrm{C}$ for $15 \mathrm{~min}$. The incubation was followed by a rapid vacuum filtration through Whatman GF/B glass filters, and the filters were washed twice with $5 \mathrm{~mL}$ cold buffer and transferred to scintillation vials. Scintillation fluid $(3.0 \mathrm{~mL})$ was added and the vials were counted the next day using a Beckman LS 6500 liquid scintillation counter. Each experiment was performed in duplicate:

Inhibition $(\%)=($ total binding - compound binding $) \times 100 \% /($ total binding - nonspecific binding $)$

\subsection{5- $H T_{2 A}$ Binding Assay [45]}

Cerebral cortex was homogenized in 20 volumes of ice-cold Tris- $\mathrm{HCl}$ buffer $(50 \mathrm{mM}, \mathrm{pH} 7.7$ at $22{ }^{\circ} \mathrm{C}$ ) using ULTRA TURAX homogeniser, and centrifuged at 32,000 $\mathrm{g}$ for $20 \mathrm{~min}$. The resulting pellet was resuspended in the same quantity of the buffer, preincubated at $37{ }^{\circ} \mathrm{C}$ for 10 min and centrifuged for $20 \mathrm{~min}$. The final pellet was resuspended in 50 volumes of the same buffer. One milliliter of the tissue suspension, $100 \mu \mathrm{L}$ of $1 \mu \mathrm{M}$ methisergide, $100 \mu \mathrm{L}$ of $\left[{ }^{3} \mathrm{H}\right]$-ketanserin and $100 \mu \mathrm{L}$ of the analyzed compound were incubated at $37^{\circ} \mathrm{C}$ for $20 \mathrm{~min}$, followed by a rapid vacuum filtration through 
Whatman GF/B glass filters, The filters were washed twice with $5 \mathrm{~mL}$ cold buffer and transferred to scintillation vials. Liquid scintillation $(3.0 \mathrm{~mL})$ was added and the vials were counted the next day using a Beckman LS6500 liquid scintillation counter. The final $\left[{ }^{3} \mathrm{H}\right]$-ketanserin concentration was $1 \mathrm{nM}$, and the concentrations of the analyzed compounds $10 \mu \mathrm{M}$. Each experiment was performed in duplicate:

Inhibition $(\%)=($ total binding - compound binding $) \times 100 \% /($ total binding - nonspecific binding $)$

\subsection{5-HT Uptake Binding Assay [46]}

A human carcinoma cell line possessing low endogenous levels of the 5-HT transporter were seeded into 96-well plates and treated with staurosporine at least $18 \mathrm{~h}$ prior to assay. On the day of assay, vehicle, excess of fluoxetine, or test compound was added to various wells on the plate. All wells then received $\left[{ }^{3} \mathrm{H}\right]-5-\mathrm{HT}$ and were incubated at $37{ }^{\circ} \mathrm{C}$ for $5 \mathrm{~min}$. The wells are then washed with ice cold $50 \mathrm{mM}$ Tris-HCl (pH 7.4) buffer and aspirated to remove free $\left[{ }^{3} \mathrm{H}\right]-5-\mathrm{HT}$. An amount of $25 \mu \mathrm{L}$ of $0.25 \mathrm{M}$ $\mathrm{NaOH}$ is then added to each well to lyse the cells and $75 \mu \mathrm{L}$ scintillation fluid added and bound radioactivity was quantitated using a Beckman LS6500 liquid scintillation counter. Tubes with vehicle represent total possible uptake, and radioactivity counted intubes with duloxetine represent nonspecific binding/uptake and is subtracted from the total possible uptake to give total possible specific uptake. This nonspecific binding (usual low in number) is then subtracted from the counts obtained in wells with various test compounds to give specific uptake in the presence of drug. Specific uptake is then expressed as a \% of control values.

\section{8. $\mu$-Opioid Receptor Binding Assay [47]}

A suspension of membranes from human $\mu$-opioid receptor-expressing $\mathrm{CHO}$ cells in $50 \mathrm{mM}$ Tris- $\mathrm{HCl}$ buffer (pH 7.4) containing $5 \mathrm{mM} \mathrm{MgCl}_{2}$ and $10 \%$ sucrose was incubated at room temperature for $2.5 \mathrm{~h}$ with $0.33 \mathrm{nM}\left[{ }^{3} \mathrm{H}\right]$-diprenorphine and $10 \mu \mathrm{M}$ of compounds. The membranes were collected by filtration using Whatman GF/B glass filters, and radio-activity was counted with a Beckman LS 6500 liquid scintillation counter. Nonspecific binding $(6.4 \%)$ was determined with $10 \mu \mathrm{M}$ naloxone. Specific binding was calculated by subtracting nonspecific binding from the total binding. Each experiment was performed in duplicate.

\section{9. k-Opioid Receptor Binding Assay [47]}

A suspension of membranes from human $k$-opioidreceptor-expressing HEK 293 cells in $50 \mathrm{mM}$ Tris buffer ( $\mathrm{pH}$ 7.4) containing $5 \mathrm{mM} \mathrm{MgCl}, 1 \mathrm{mM}$ EDTA, and $10 \%$ sucrose was incubated at room temperature for $1 \mathrm{~h}$ with $0.41 \mathrm{nM}\left[{ }^{3} \mathrm{H}\right]$-diprenorphine and $10 \mu \mathrm{M}$ of compounds. The membranes were collected by filtration using Whatman GF/B glass filters, and radioactivity was counted with a Beckman LS6500 liquid scintillation counter. Nonspecific binding (2.3\%) was determined with $100 \mu \mathrm{M}$ naloxone. Specific binding was calculated by subtracting nonspecific binding from the total binding. 


\subsection{0. $\delta$-Opioid Receptor Binding Assay [47]}

A suspension of membranes from human $k$-opioidreceptor-expressing receptor-expressing $\mathrm{CHO}$ cells in $50 \mathrm{mM}$ Tris- $\mathrm{HCl}$ buffer (pH 7.4) containing $5 \mathrm{mM} \mathrm{MgCl}_{2}$ and $10 \%$ sucrose was incubated at room temperature for $1 \mathrm{~h}$ with $0.55 \mathrm{nM}\left[{ }^{3} \mathrm{H}\right]$-diprenorphine and $10 \mu \mathrm{M}$ of compounds. The membranes were collected by filtration using Whatman GF/B glass filters, and radioactivity was counted with a Beckman LS6500 liquid scintillation counter. Nonspecific binding (2.3\%) was determined with $100 \mu \mathrm{M}$ naloxone. Specific binding was calculated by subtracting nonspecific binding from the total binding.

\subsection{Statistical Analysis}

The results are presented as means \pm SEM. The statistical significance between the groups was determined by analysis of variance followed by Dunnett's multiple comparison test. P-values of less than 0.05 were considered indicative of significance.

\section{Conclusions}

In conclusion, the proposed piperazine derivatives, compounds $\mathbf{1 0 - 2 8}$, possessed a broad spectrum of analgesic activity. Compounds 18 and 19 showed remarkable analgesic activity in both the writhing and hot plate tests. They have also also shown good safety margins without sedative side effects. Furthermore, compound $\mathbf{1 8}$ could significantly reduce licking time in the formalin-induced model, and was even more active than morphine. As a non-opioid analgesic agent with high efficacy, the effectiveness of compound $\mathbf{1 8}$ is equal to that of gabapentin in the neuropathic pain models. Thus, our results suggested that compound $\mathbf{1 8}$ may be a good drug candidate for effective neuropathic pain treatment.

\section{Acknowledgements}

The authors gratefully acknowledge the financial support from the National Science and Technology Major Project “Key New Drug Creation and Manufacturing Program” (2009ZX09103-082) and the National Basic Research Program of China (2011CB910400).

\section{References}

1. Woolf, C.J. The pathophysiology of peripheral neuropathic pain-abnormal peripheral input and abnormal central processing. Acta Neurochir. Suppl. (Wien) 1993, 58, 125-130.

2. Galer, B.S. Neuropathic pain of peripheral origin: Advances in pharmacologic treatment. Neurology 1995, 45, S17-S25.

3. Attal, N.; Martinez, V. Recent developments in the pharmacological management of neuropathic pain. Eur. Neurol. J. 2010, 2, 25-30.

4. Naef, M.; Curatolo, M.; Petersen-Felix, S.; Arendt-Nielsen, L.; Zbinden, A.; Brenneisen, R. The analgesic effect of oral delta-9-tetrahydrocannabinol (THC), morphine, and a THC-morphine combination in healthy subjects under experimental pain conditions. Pain 2003, 105, 79-88. 
5. Bombardier, C.; Laine, L.; Reicin, A.; Shapiro, D.; Burgos-Vargas, R.; Davis, B.; Day, R.; Ferraz, M.B.; Hawkey, C.J.; Hochberg, M.C.; et al. Comparison of upper gastrointestinal toxicity of rofecoxib and naproxen in patients with rheumatoid arthritis. N. Engl. J. Med. 2000, 23, 1520-1528.

6. Mattia, C.; Coluzzi, F. Antidepressants in chronic neuropathic pain. Mini Rev. Med. Chem. 2003, 3, 773-784.

7. Gutierrez-Alvarez, A.M.; Beltrán-Rodríguez, J.; Moreno, C.B. Antiepileptic drugs in treatment of pain caused by diabetic neuropathy. J. Pain Symptom Manag. 2007, 34, 201-208.

8. White, P.F. The changing role of non-opioid analgesic techniques in the management of postoperative pain. Anesth. Analg. 2005, 101, 5-22.

9. Gilron, I.; Coderre, T.J. Emerging drugs in neuropathic pain. Expert Opin. Emerg. Drugs 2007, 12, 113-126.

10. Chong, M.S.; Brandner, B. Neuropathic agents and pain. New strategies. Biomed. Pharmacother. 2006, 60, 318-322.

11. Gan, L.L.; Cai, J.L.; Zhou, C.H. Advances in piperazine-containing compounds as receptor ligands. Chin. Pharm. J. 2009, 44, 1361-1368.

12. Gan, L.L.; Lu, Y.H.; Zhou, C.H. Advances in the research of piperazine compounds as enzyme inhibitors. Chin. J. Biochem. Pharm. 2009, 30, 127-131.

13. Willems, L.I.; Ilzerman, A.P. Small molecule antagonists for chemokine $\mathrm{CCR}_{3}$ receptors. Med. Chem. Res. 2010, 30, 778-817.

14. Karbarz, M.J.; Luo, L.; Chang, L.; Tham, C.S.; Palmer, J.A.; Wilson, S.J.; Wennerholm, M.L.; Brown, S.M.; Scott, B.P.; Apodaca, R.L.; et al. Biochemical and biological properties of 4-(3-phenyl-[1,2,4]thiadiazol-5-yl)-piperazine-1-carboxylic acid phenylamide, a mechanism-based inhibitor of fatty acid amide hydrolase. Anesth. Analg. 2009, 108, 316-329.

15. Drizin, I.; Gregg, R.J.; Scanio, M.J.; Shi, L.; Gross, M.F.; Atkinson, R.N.; Thomas, J.B.; Johnson, M.S.; Carroll, W.A.; Marron, B.E.; et al. Discovery of potent furan piperazine sodium channel blockers for treatment of neuropathic pain. Bioorg. Med. Chem. 2008, 16, 6379-6386.

16. Pajouhesh, H.; Feng, Z.P.; Ding, Y.B.; Zhang, L.Y.; Pajouhesh, H.; Morrison, J.L.; Belardetti, F.; Tringham, E.; Simonson, E.; Vanderah, T.W.; et al. Structure-activity relationships of diphenylpiperazine N-type calcium channel inhibitors. Bioorg. Med. Chem. Lett. 2010, 20, 1378-1383.

17. Borza, I.; Domany, G. $\mathrm{NR}_{2} \mathrm{~B}$ selective NMDA antagonists: The evolution of the ifenprodil-type pharmacophore. Curr. Top. Med. Chem. 2006, 6, 687-695.

18. Li, J.Q.; Huang, L.Y.; Chen, J.X.; Weng, Z.J.; Zhang, C.N. Design and synthesis of aralkyl-ketone piperazine derivatives and their antalgic activities. Yaо Хие Хие Вао 2007, 42, 1166-1175, in Chinese.

19. Li, J.Q.; Huang, L.Y.; Chen, J.X.; Weng, Z.J.; Zhang, C.N. Synthesis and central none-opioid analgesic activity of SIPI5047. Yaо Хие Хие Bao 2008, 43, 611-618, (in Chinese).

20. Zhang, W.; Curran, D.P.; Chen, C.H.-T. Use of fluorous silica gel to separate fluorous thiol quenching derivatives in solution-phase parallel synthesis. Tetrahedron 2002, 58, 3871-3875.

21. Coolier, H.O.J.; Dinneen, L.C.; Johnson, C.A.; Schneider, C. The abdominal constriction response and its suppression by analgesic drugs in the mouse. Br. J. Pharmacol. Chemother. 1968, 32, 295-310. 
22. Kuraishi, Y.; Harada, Y.; Aratani, S.; Satoh, M.; Takagi. H. Separate involvement of the spinal noradrenergic and serotonergic systems in morphine analgesia: The differences in mechanical and thermal algesic tests. Brain Res. 1983, 273, 245-252.

23. Litchfield, J.T.; Wilcoxon, F. A simplified method of evaluating dose-effect experiments. J. Pharmacol. Exp. Ther. 1949, 96, 99-113.

24. Butini, S.; Gemma, S.; Campiani, G.; Franceschini, S.; Trotta, F.; Borriello, M.; Ceres, N.; Ros, S.; Coccone, S.S.; Bernetti, M.; et al. Discovery of a new class of potential multifunctional atypical antipsychotic agents targeting dopamine $\mathrm{D}_{3}$ and serotonin 5- $\mathrm{HT}_{1 \mathrm{~A}}$ and 5- $\mathrm{HT}_{2 \mathrm{~A}}$ receptors: Design, synthesis, and effects on behavior. J. Med. Chem. 2009, 52, 151-169.

25. Hurley, R.W.; Chatterjea, D.; Rose Feng, M.H.; Taylor, C.P.; Hammond, D.L. Gabapentin and pregabalin can interact synergistically with naproxen to produce antihyperalgesia. Anesthesiology 2002, 97, 1263-1273.

26. Pedersen, L.H.; Blackburn-Munro, G. Pharmacological characterisation of place escape/avoidance behaviour in the rat chronic constriction injury model of neuropathic pain. Psychopharmacology 2006, 185, 208-217.

27. Hayashida, K.; Parker, R.; Eisenach, J.C. Oral gabapentin activates spinal cholinergic circuits to reduce hypersensitivity after peripheral nerve injury and interacts synergistically with oral donepezil. Anesthesiology 2007, 106, 1213-1219.

28. Bars, D.L.; Gozariu, M.; Cadden, S.W. Animal models of nociception. Pharmacol. Rev. 2001, 53, 597-652.

29. Dworkin, R.H. An overview of neuropathic pain: Syndromes, symptoms, signs, and several mechanisms. Clin. J. Pain. 2002, 18, 343-349.

30. Butera. J.A. Current and emerging targets to treat neuropathic pain. J. Med. Chem. 2007, 50, 2543-2546.

31. Decosterd, I.; Woolf, C. Spared nerve injury: An animal model of persistent peripheral neuropathic pain. Pain 2000, 87, 149-158.

32. Bennett, G.J.; Xie, Y.K. A peripheral mononeuropathy in rat that produces disorders of pain sensation like those seen in man. Pain 1988, 33, 87-107.

33. Mico, J.A.; Berrocoso, E.; Ortega-Alvaro, A.; Gibert-Rahola, J.; Rojas-Corrales, M.O. The role of $5-\mathrm{HT}_{1 \mathrm{~A}}$ receptors in research strategy for extensive pain treatment. Curr. Top. Med. Chem. 2006, 6, 1997-2003.

34. Fasmer, O.B.; Berge, O.G.; Post, C.; Hole, K. Effects of the putative 5-HT $1 \mathrm{~A}$ receptor agonist 8-OH-2-(di-n-propylamino)tetralin on nociceptive sensitivity in mice. Pharmacol. Biochem. Behav. 1986, 25, 883-888.

35. Bardin, L.; Tarayre, J.P.; Malfetes, N.; Koek, W.; Colpaert, F.C. Profound, non-opioid analgesia produced by the high-efficacy 5-HT1A agonist F 13640 in the formalin model of tonic nociceptive pain. Pharmacology 2003, 67, 182-194.

36. Deseure, K.R.; Adriaensen, H.F.; Colpaert, F.C. Effects of the combined continuous administration of morphine and the high-efficacy 5-HT1A agonist, F 13640 in a rat model of trigeminal neuropathic pain. Eur. J. Pain 2004, 8, 547-554. 
37. Kiss, I.; Degryse, A.D.; Bardin, L.; Gomez de, S.I.A.; Colpaert, F.C. The novel analgesic, F 13640, produces intra- and postoperative analgesia in a rat model of surgical pain. Eur. J. Pharmacol. 2005, 523, 29-39.

38. Paluchowska, M.; Mokrosz, M.J.; Charakchieva-Minol, S. Duszyńska, B.; Kozioł, A.; Wesołowska, A.; Stachowicz, K.; Chojnacka-Wójcik, E. Novel 4-alkyl-1-arylpiperazines and 1,2,3,4-tetrahydroisoquinolines containing diphenylmethylamino or diphenylmethoxy fragment with differentiated 5-HT1A/5-HT2A/D2 receptor activity. Pol. J. Pharmacol. 2003, 55, 543-552.

39. Obniska, J.; Pawlowski, M.; Kolaczkowski, M.; Czopek, A.; Duszynska, B.; Klodzinska, A.; Tatarczynska, E.; Chojnacka-Wojcik, E. Synthesis and $5-\mathrm{HT}_{1 \mathrm{~A}} / 5-\mathrm{HT}_{2 \mathrm{~A}}$ receptor affinity of new $\mathrm{N}$-[(4-arylpiperazin-1yl)-propyl] derivatives of 3-spirocyclohexanepyrrolidine-2,5-dione and 3-spiro- $\beta$-tetralonepyrrolidine-2,5-dione. Pol. J. Pharmacol. 2003, 55, 553-557.

40. Obniska, J.; Kolaczkowski, M.; Charakchieva-Minol, S.; Nedza, K.; Dybala, M.; Bojarski, A.J.; Synthesis, anticonvulsant properties and $5-\mathrm{HT}_{1 \mathrm{~A}} / 5-\mathrm{HT}_{2 \mathrm{~A}}$ receptor affinity of new $\mathrm{N}$-[(4-arylpiperazin-1yl)-propyl]-2-aza-spiro[4.4]-nonane and [4.5]decane-1,3-dione derivatives. Pharmacol. Rep. 2005, 57, 336-344.

41. Erichsen, H.K.; Blackburn-Munro, G. Pharmacological characterisation of the spared nerve injury model of neuropathic pain. Pain 2002, 98, 151-161.

42. Chaplan, S.R.; Bach, F.W.; Pogrel, J.W.; Chung, J.M.; Yaksh, T.J. Quantitative assessment of tactile allodynia in the rat paw. J. Neurosci. Methods 1994, 53, 55-63.

43. Hargreaves, K.; Dubner, R.; Brown, F.; Flores, C.; Joris, J. A new and sensitive method for measuring thermal nociception in cutaneous hyperalgesia. Pain 1988, 32, 77-88.

44. Frecentese, F.; Fiorino, F.; Perissutti, E.; Severino, B.; Magli, E.; Esposito, A.; Angelis, F.D.; Massarelli, P.; Nencini, C.; Viti, B.; et al. Efficient microwave combinatorial synthesis of novel indolic arylpiperazine derivatives as serotoninergic ligands. Eur. J. Med. Chem. 2010, 45, $752-759$.

45. Brea, J.; Rodrigo, J.; Carrieri, A.; Sanz, F.; Cadavid, M.I.; Enguix, M.J.; Villazon, M.; Mengod, G.; Caro, Y.; Masaguer, C.F.; et al. New serotonin 5-HT(2A), 5-HT(2B), and 5-HT(2C) receptor antagonists: Synthesis, pharmacology, 3D-QSAR, and molecular modeling of (aminoalkyl)benzo and heterocycloalkanones. J. Med. Chem. 2002, 45, 54-71.

46. Hatzenbuhler, N.T.; Baudy, R.; Evrard, D.A.; Failli, A.; Harrison, B.L.; Lenicek, S.; Mewshaw, R.E.; Saab, A.; Shah, U.; Sze, J.; et al. Advances toward new antidepressants with dual serotonin transporter and 5-HT1A receptor affinity within a class of 3-aminochroman derivatives. Part 2. J. Med. Chem. 2008, 51, 6980-7004.

47. Shinkai, H.; Ito, T.; Iida, T.; Kitao, Y.; Yamada, H.; Uchida, I. 4-Aminoquinolines: Novel nociceptin antagonists with analgesic activity. J. Med. Chem. 2000, 43, 4667-4677.

Sample Availability: Samples of the compounds are available from the authors.

(C) 2011 by the authors; licensee MDPI, Basel, Switzerland. This article is an open access article distributed under the terms and conditions of the Creative Commons Attribution license (http://creativecommons.org/licenses/by/3.0/). 